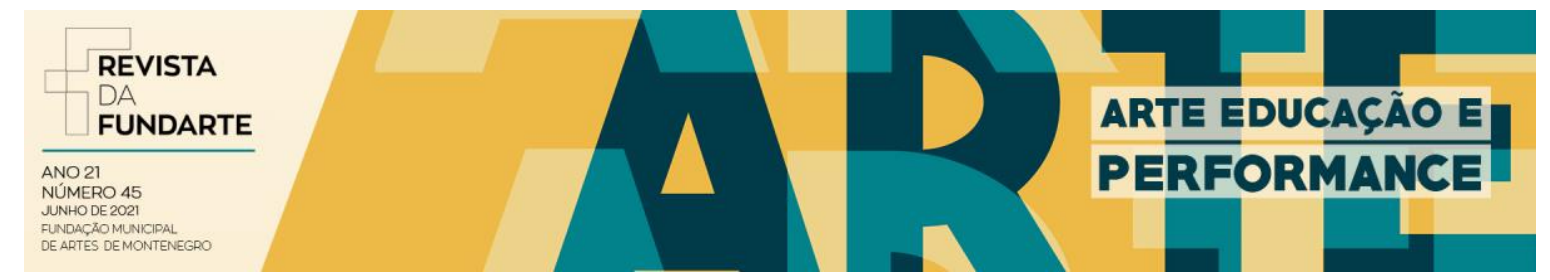

\title{
MANIFESTAÇÕES DO GROTESCO EM MARK MORRISROE, ROBERT MAPPLETHORPE E RUDOLF SCHWARZKOGLER
}

Claudimar Pereira Silva

DOI: $10.19179 / 2319-0868 / 867$ 


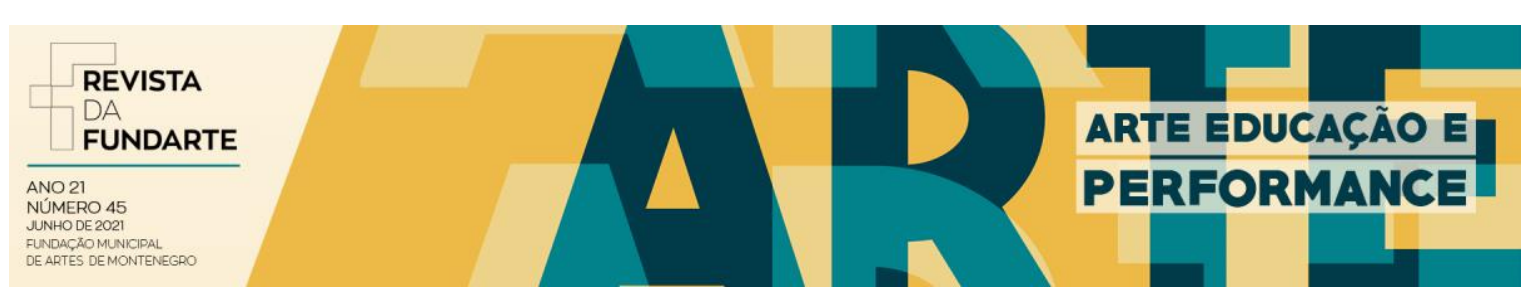

\title{
MANIFESTAÇÕES DO GROTESCO EM MARK MORRISROE, ROBERT MAPPLETHORPE E RUDOLF SCHWARZKOGLER
}

Claudimar Pereira Silva ${ }^{1}$

\begin{abstract}
Resumo: Este artigo objetiva a análise das manifestações do grotesco nas obras de três artistas fundamentais do século XX: os norte-americanos Mark Morrisroe (1959-1989) e Robert Mapplethorpe (1946-1989), e o austríaco Rudolf Schwarzkogler (1940-1969). A partir dos pressupostos teóricos sobre o grotesco de Wolfgang Kayser (1986), Mikhail Bakhtin (1998) e Santos (2009), além de comentadores das obras dos artistas em questão, pretende-se analisar o modo como esta categoria estética manifesta-se em um pequeno corpus de obras selecionadas dos três fotógrafos, artistas marginais que propuseram novas formas de compreensão estética da imagem e da arte, mediante à representação da doença, do abjeto e do escatológico.
\end{abstract}

Palavras-chave: Grotesco; Fotografia; Corpos.

\section{MANIFESTATIONS OF THE GROTESQUE IN MARK MORRISROE, ROBERT MAPPLETHORPE AND RUDOLF SCHWARZKOGLER}

\begin{abstract}
This article aims to analyze the manifestations of the grotesque in the works of three fundamental artists of the $20^{\text {th }}$ century: the North-americans Mark Morrisroe (1959-1989) and Robert Mapplethorpe (1946-1989) and the Austrian Rudolf Schwarzkogler (1940-1969). Based on the theoretical assumptions about the grotesque of Wolfgang Kayser (1986), Mikhail Bakhtin (1998) and Santos (2009), and commentators on the works of the artists in question, we intend to analyze how this aesthetic category manifests itself in a small corpus of selected works by these three photographers, marginalized artists who proposed new forms of aesthetic understanding of image and art, through the representation of the disease, the abject and the eschatological.
\end{abstract}

Keywords: Grotesque; Photography; Bodies.

\footnotetext{
1 Doutorando pelo Programa de Pós-Graduação em Estudos Literários da Universidade Estadual Paulista "Júlio de Mesquita Filho" (UNESP), campus de Araraquara. Atualmente desenvolve pesquisa sobre as representações das masculinidades na obra de William Faulkner. Obteve o título de mestre pela mesma instituição, onde defendeu dissertação sobre a narrativa poética e a fragmentação em William Faulkner, com apoio financeiro do CNPq (Centro Nacional de Pesquisa e Desenvolvimento). Licenciado e bacharel em Letras nas áreas de Português-Inglês pela Universidade Estadual Paulista (UNESP). Durante a graduação, desenvolveu pesquisa sobre a questão do narrador na obra de William Faulkner, no módulo IC (iniciação científica), com o fomento científico da FAPESP (Fundação de Amparo à Pesquisa do Estado de São Paulo). Possui artigos publicados em periódicos da área de Estudos Literários, e tem como áreas de interesse o romance modernista e pós-moderno, as relações intersemióticas, a história da arte, o cinema avant-garde e experimental, a iconografia homoerótica, a literatura estadunidense e os estudos de gênero, mais especificamente no que tange às representações das masculinidades no texto literário.
} 


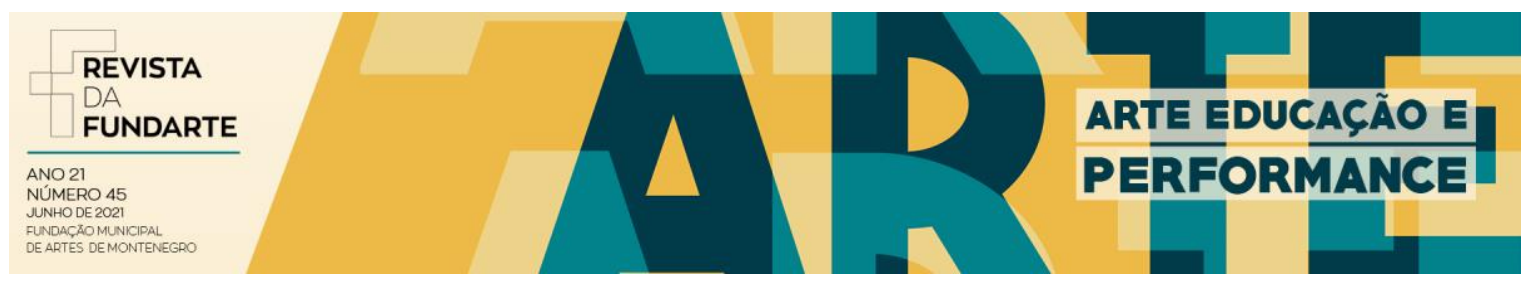

\section{A TRINDADE UNDERGROUND}

O fotógrafo americano Mark Morrisroe viveu apenas trinta anos. Canonizado como apóstolo do underground e pária da sociedade estadunidense em pleno zênite do governo puritano de Ronald Reagan na década de 1980, Morrisroe fundamentou obras de textura residual e experimental, apostando numa estética transgressora e predominantemente confessional e autobiográfica. Mesclando interferências manuais às suas fotografias, nas quais representava os desvalidos e outsiders da cena gay punk de Boston e Nova York, além de fotografar a si mesmo - inclusive em estado terminal em decorrência da Aids, em 1989 - Morrisroe ressignificou o conceito moralista de promiscuidade sexual adotando-o como estilo de vida, tendo trabalhado até mesmo como hooker (garoto de programa) nas ruas de Boston, sob o pseudônimo de Mark Dirt (ALVES, 2016).

Enquanto isso, Morrisroe condensava suas experiências sexuais e vivência junky em objetos estéticos que resvalam para o político e transgridem os valores predeterminados da moralidade sexual, dos padrões gays de consumo do american way of life e do próprio status da fotografia como arte e linguagem. $\mathrm{Na}$ contemporaneidade, as polaroids de Morrisroe emergiram de um limbo de esquecimento nos anos 1990 e 2000, se transformando em artefatos cults que documentam a beleza íntima da alegria e da liberdade sórdida.

Contemporâneo de Mark Morrisroe, Robert Mapplethorpe também estruturou um corpus imagético desafiador dos cânones do belo e da arte institucionalizada na cultura norte-americana do pós-guerra. Ora fotografando celebridades, e catalisando experiências em torno do culto a elas (Patti Smith e Andy Warhol incluem-se nesse panteão), ora imagens que fusionam lirismo e erotismo, Mapplethorpe fundou uma obra cuja etimologia da palavra fotografia, isto é, algo que é grafado pela luz, assume conotações límpidas: seus nus, femininos, masculinos e andróginos, trazem à tona as materialidades corpóreas em pequenos tableaux ousados e sombrios, nos quais as metáforas são alongadas a ponto de colapsarem na superfície imagética 


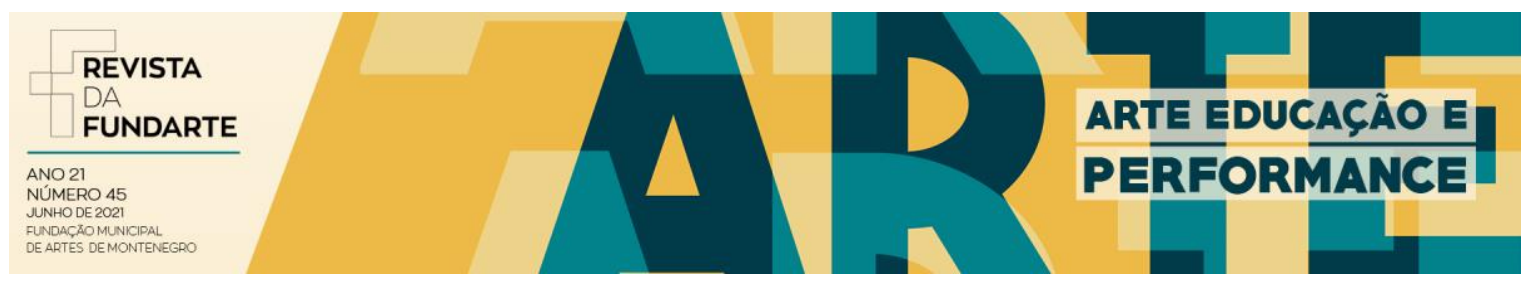

imediata e resvalarem para uma poética da delicadeza, da sensibilidade aurática e escatológica dos corpos e objetos.

De flores a corpos masculinos, Mapplethorpe parecia preocupar-se primeiramente com o impacto imediato da obra nas retinas do espectador, e os modos de organização de tais imagens nas camadas hermenêuticas de sensorialidade estética na superfície de sua recepção. Mapplethorpe, como Morrisroe, vitimado pela Aids em 1989, passeava tranquilamente dos espaços bem iluminados e ostentosos do jet set nova-iorquino às masmorras da maçonaria gay underground, onde convivem sadomasoquistas, leathers e fetichistas (SILVA \& SILVA, 2016, p. 267-268).

Apenas alguns anos antes, o fotógrafo e artista performático austríaco Rudolf Schwarzkogler, como Morrisroe e Mapplethorpe, morreria muito jovem, aos vinte e nove anos. Nesse curto período de vida, Schwarzkogler levou aos limites os preceitos da body art, isto é, a ramificação da arte da performance que mobiliza o corpo e as corporalidades como suporte e anteparo para a realização de obras (ARCHER, 2012, p. 111). Inserido no grupo restrito e radical do Viennese actionism, que agrupava nomes essenciais para a arte europeia do século $\mathrm{XX}$, como Otto Muehl, Hermann Nitsch e Günter Brus, Schwarzkogler, em seu trabalho com a fotografia, documentou imagens de grande densidade simbólica que operam no acumulamento obscuro das pulsões de destruição: suas fotografias de corpos embalsamados, pênis mutilados, objetos cirúrgicos, rostos asfixiados, peles suturadas e animais estripados, possibilitaram à arte o exercício ontológico de olhar a si mesma como potencialidade de colapso, pulsão de morte e ritualística de (auto) sacrifício. Há inclusive a mitologia arraigada de que a morte prematura de Schwarzkogler teria ocorrido devido às mutilações do artista em seu pênis durante uma performance, fato esse já desmentido por pesquisadores de sua obra (PECORELLI, 2019, p. 73).

Estes três artistas, em suas poéticas e mitologias pessoais, constituem uma genealogia de obras fotográficas nas quais a morte, o erotismo, a doença, a violência, a pornografia e a escatologia operam como componentes que possibilitam 


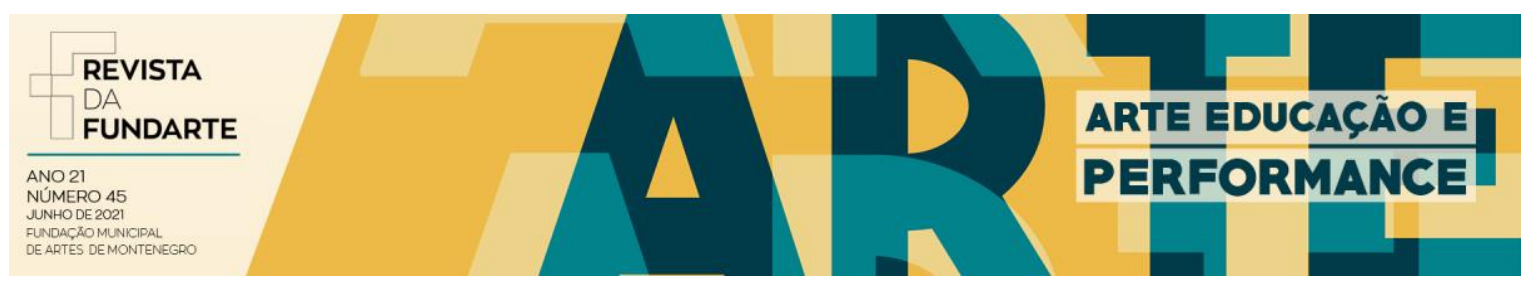

a exegese de tais imagens a partir da categoria estética do grotesco (KAYSER, 1986). Apesar de estarem situados em temporalidades e espacialidades distintas e de apresentarem sistemas representativos diversos, Morrisroe, Mapplethorpe e Schwarzkogler convergem no eixo questionador dos padrões estabelecidos da estética e da moralidade visual e sexual, ao representarem a beleza de corpos esquálidos e doentes, do sangue, fluidos e fezes de animais eviscerados, além da fisiologia pegajosa do baixo corporal, isto é, os órgãos sexuais e cavidades anais.

Kayser (1986) define o grotesco como a aparição estética do disforme, do feio e do anômalo nas obras de arte, à qual, na dialética da recepção, produz efeitos de riso, náusea, estranhamento ou desorientação. Assim, para o autor, "o conceito de grotesco ficou arrastando-se através dos livros de estética como subclasse do cômico, ou, mais precisamente, do cru, baixo, burlesco, ou então, do cômico, do mau gosto" (KAYSER, 1986, p. 14). No entanto, Kayser se refere à possibilidade de que obras sejam percebidas como grotescas, mas cujos sistemas internos de representação não tenham sido dispostos necessariamente com essa finalidade. Diante disso, diz Kayser, "continua válido o fato de que o grotesco só é experimentado na recepção" (1986, p. 156).

Análogo a Kayser, Bakhtin (1987) define o grotesco como a manifestação do exagero e do cômico, no modo como estes elementos articulam-se à dimensão sensorial do folclore e das festas populares. Ao analisar a obra de Rabelais, Bakhtin chega à conclusão de que o grotesco tange à potencialidade transgressora e criativa dos folguedos e festas populares, como o carnaval, cujas inversões paródicas possibilitam a construção de discursos críticos e carnavalizados sobre a realidade, por meio de expressões do baixo corporal, da escatologia e do riso (BAKHTIN, 1987, p. 45).

Santos (2009), por sua vez, analisa o grotesco a partir de sentidos de alteridade, de componentes que residem além da dialética da recepção: "o grotesco é uma estética do outro. O grotesco em geral emana do polo de uma alteridade que se mostra, por vezes, desorientadora, incompreensível, incerta ou mesmo hostil ao 


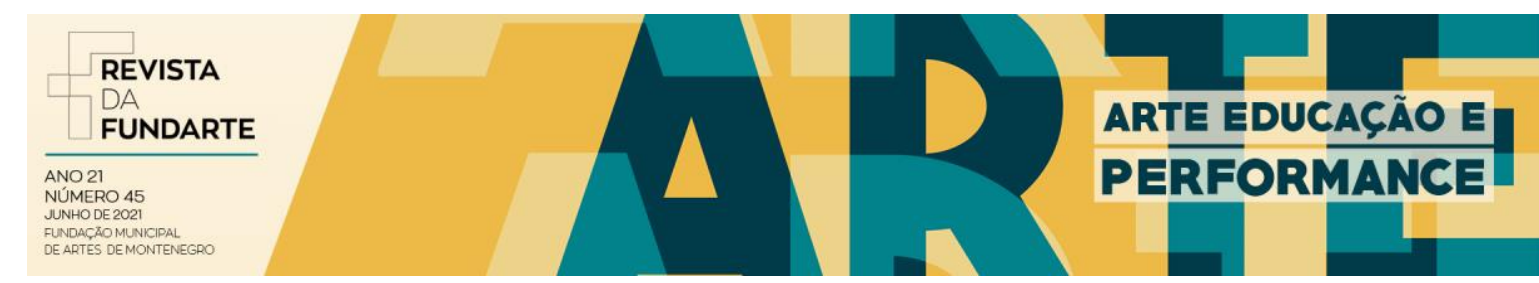

senso-comum" (SANTOS, 2009, p. 138, grifo do autor). O autor prossegue, ressaltando que o grotesco reside justamente

\begin{abstract}
na outra cultura, expressa pelos costumes populares em relação ao modus vivendi oficial; nos outros reinos da vida, manifestados pelo bestialógico; nos outros estados de consciência entrevistos nos surtos de loucura e nas manifestações do inconsciente e no outro eu que toma forma nos simulacros, nos autômatos, nos monstros e nos duplos. Como o grotesco demonstra ser uma categoria pautada nos contrastes, esses outros que o caracterizam, mormente, são apresentados relacionando-se diretamente com a realidade cotidiana, e, no romantismo, costumam invadir a vida comum, ameaçando desestruturá-la. (SANTOS, 2009, p. 138, grifo do autor).
\end{abstract}

Ora, se como define Santos (2009), o grotesco é uma estética do outro, de outra cultura, uma abordagem calcada na alteridade, logo, se tornam plausíveis as possibilidades analíticas referentes às obras dos três artistas que fundamentam o corpus deste artigo. Ambos, como já ressaltamos, são fotógrafos que transitaram pelo que denominamos aqui de uma cultura underground - compreendida como o modus vivendi oriundo de espaços subterrâneos, independente do status quo, e que se estabelece na direção contrária às instituições burguesas, geralmente atrelada à neovanguarda surgida nas décadas de 1950 a 1970. O princípio de alteridade reside até mesmo na biografia marginalizada desses artistas: dois deles eram abertamente gays (Morrisroe e Mapplethorpe), e abordaram essa temática em obras que solapam os valores tradicionais do cânone fotográfico.

Sendo assim, este artigo objetiva a análise das aparições do grotesco em fotografias de Mark Morrisroe, Robert Mapplethorpe e Rudolf Schwarzkogler, a partir de um recorte específico de imagens selecionadas. Diante disso, o corpus do artigo consiste em: 1) a série de fotografias finais de Mark Morrisroe, em que ele registra seu processo de adoecimento pela Aids, em 1989; 2) quatro fotografias de Robert Mapplethorpe que apresentam a prática sexual do fist fucking, isto é, a penetração de braços e punhos no ânus; 3) um conjunto de quatro fotografias de Rudolf Schwarzkogler, nas quais ele documenta performances de grande complexidade conceitual. 


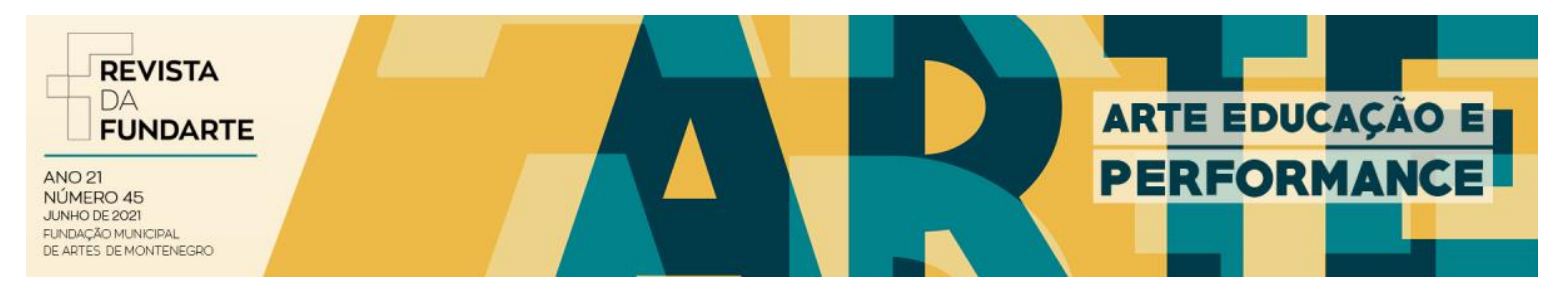

\section{O CORPO ESQUÁLIDO DE MARK MORRISROE}

Como já assinalamos, Mark Morrisroe era um fotógrafo habitué da cena gay independente de Boston na década de 1970 e posteriormente, Nova York, nos anos 1980. Sua obra caracteriza-se pelo teor erotizante e confessional, e pela documentação lírica de corpos - de amantes, amigos ou do próprio artista - a partir de bricolagens manuais nas fotografias (DRISCOLL, 2013, p. 1-2). Depois do diagnóstico de portador do HIV em 1986, o fotógrafo passou por diversas internações, e durante tais períodos, trabalhava em estúdios improvisados em banheiros de hospitais. Era no processo de revelação de suas imagens que Morrisroe interferia, utilizando objetos, desenhos, arranhões, letra cursiva, fotogramas, e até mesmo prontuários médicos na composição final (2013, p. 3). Desses trabalhos, selecionamos quatro fotografias que, analisadas em contraponto, possibilitam a assimilação do grotesco que poreja em suas superfícies.

A primeira sequência de imagens mostra o artista internado em um hospital de Nova York. Na primeira fotografia (Fig. 1), Morrisroe aparece sentado na cama, destacando-se, com o pijama hospitalar, da penumbra que domina o fundo. $\mathrm{O}$ artista está mais magro, mas ainda assim parece relativamente saudável. Aparelhos médicos estão ligados ao corpo do fotógrafo, como pode ser observado pelo enfaixamento de seu punho esquerdo. Apesar do instante brutalmente real, em particular no final da década de 1980 - um paciente doente por Aids, quando esta significava uma sentença de morte - há algo na imagem que resvala para o irreal, o fantasmagórico, provavelmente pela luminosidade do leito e da veste hospitalar de Morrisroe. A expressão do fotógrafo, seu olhar baixo que evita o olhar imaginário do espectador - o que vemos, o que nos olha, postularia Didi-Huberman (2010) conjuga sentimentos de fragilidade, melancolia e resignação. 

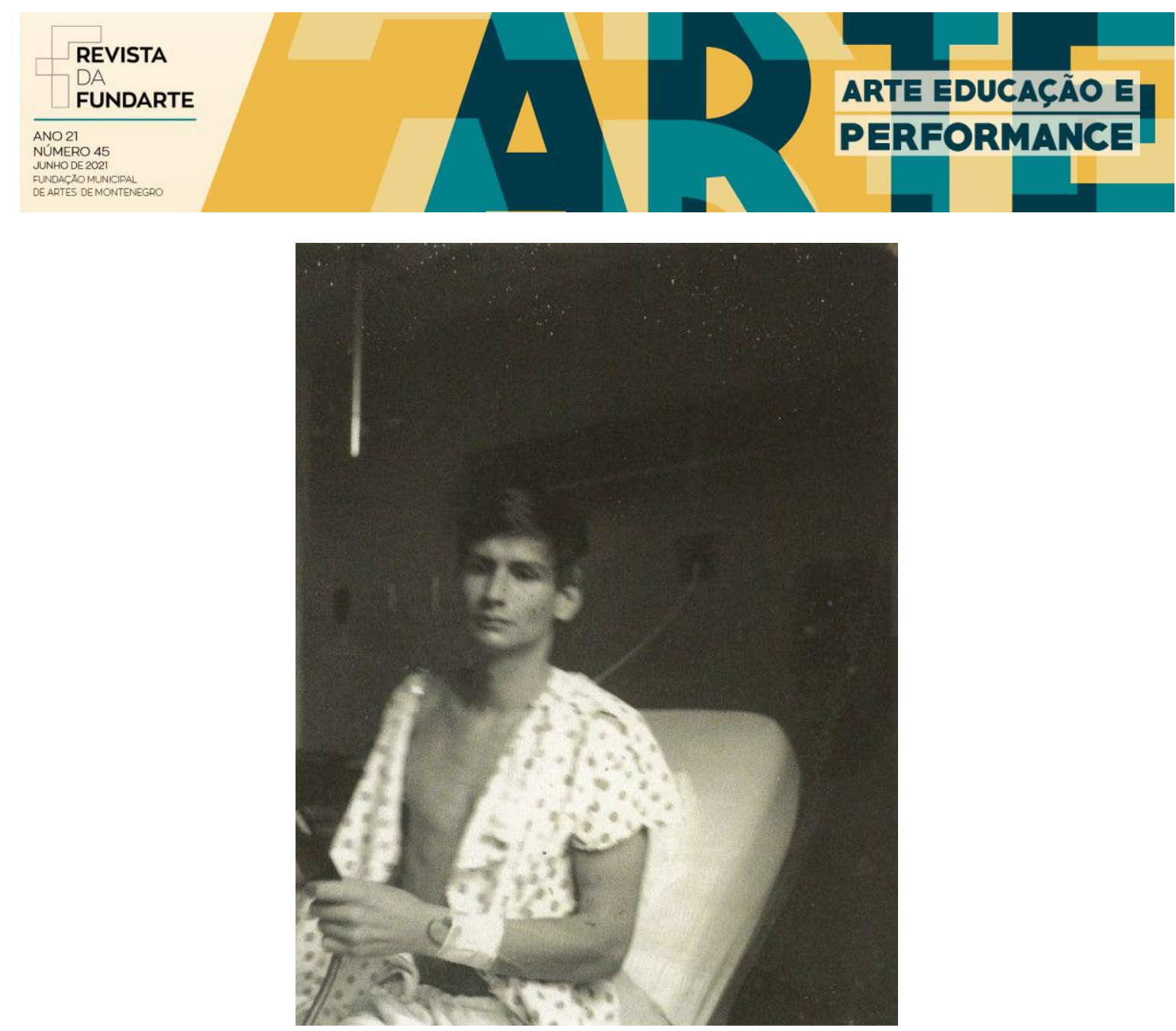

Fig. 1. Mark Morrisroe, Untitled (self-portrait), 1988. Polaroid T-665, 10, 7 x 8,5 cm. Zurique, Suíça. Fonte: JRP Ringier: Catálogo, 2010.

A segunda foto (Fig. 2), por sua vez, conjuga todos os elementos da anterior, modificando-se apenas a postura adotada pelo fotógrafo. Panorâmica, nela Morrisroe aparece deitado de lado, enquanto fita diretamente o espectador. As nádegas, escroto e pernas estão à mostra, enquanto o braço do artista - no qual estão atrelados a aparelhagem de transfusão - pende da cama, de maneira lânguida. A expressão de Morrisroe é um híbrido de insolência, melancolia e sensualidade. Além disso, a longa haste metálica da sustentação do soro fratura a imagem em duas partes quase equivalentes. O erotismo da composição é evidente: as nádegas descobertas de Morrisroe próximas a esta representação do falo figuram como resíduo e memória permanentes de que o fotógrafo, mesmo enfermo, ainda se estabelece como corpo desejante, princípio de vida e de afirmação, corpo-tábula no qual a Aids inscrevia seu codex de sintomas estigmatizantes ainda discretamente, de modo bastante distinto das imagens que viriam em seguida. 

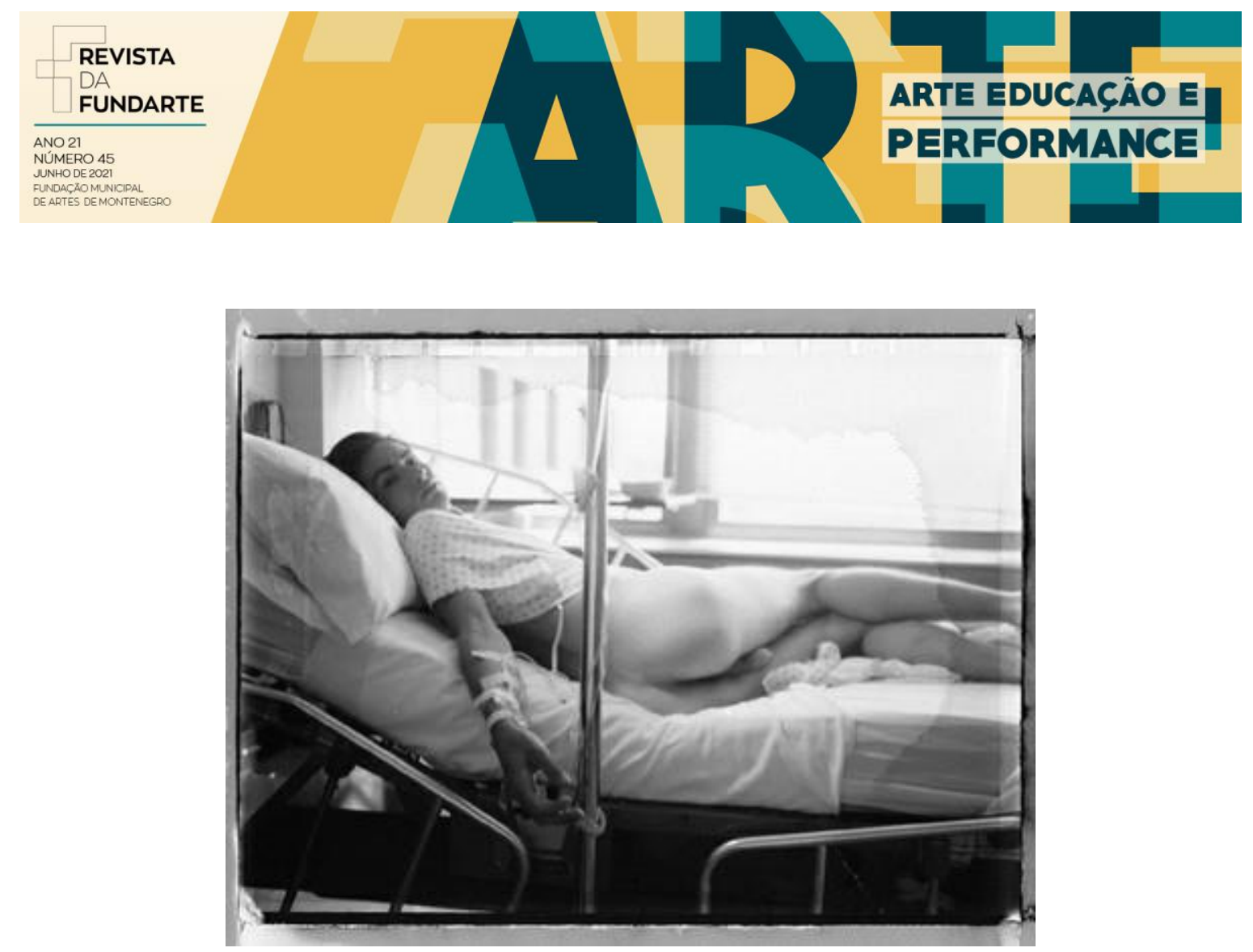

Fig. 2. Mark Morrisroe, Untitled (self-portrait), 1988. Polaroid T-665, 10, 7 x 8,5 cm. Zurique, Suíça. Fonte: JRP Ringier: Catálogo, 2010.

As duas fotos seguintes datam do ano de 1989, portanto um ano depois das anteriores. Na primeira imagem da série (Fig. 3), Morrisroe está nu, sentado em um canto de seu quarto. Em estado avançado, a Aids já devasta seu corpo. O artista aparece de perfil, sentado, com ambas as mãos envolvendo os joelhos, enquanto uma réstia de sol entra pela janela - espectralmente - e ilumina seu corpo. Medo, fragilidade e algo de onírico perpassa a construção do quadro, como se Morrisroe tivesse subitamente visualizado algo de estranho em seu espaço íntimo, e tivesse se encolhido. É nesse sentido que julgamos que a obra final de Morrisroe possa ser analisada a partir de um método escotográfico ${ }^{2}$ de composição, que aqui manifestase como representação do irrepresentável, do ectoplásmico, já que suas imagens apresentam um corpo em decadência física, um cadáver em devir, diante da morte iminente. Assim, pode-se considerar que Morrisroe, nestas fotografias derradeiras,

\footnotetext{
2 A escotografia refere-se à iconografia parapsicológica, e, por isso, não embasada cientificamente, de manifestações de mortos, espíritos, presenças ou fantasmas em fotografias.
} 


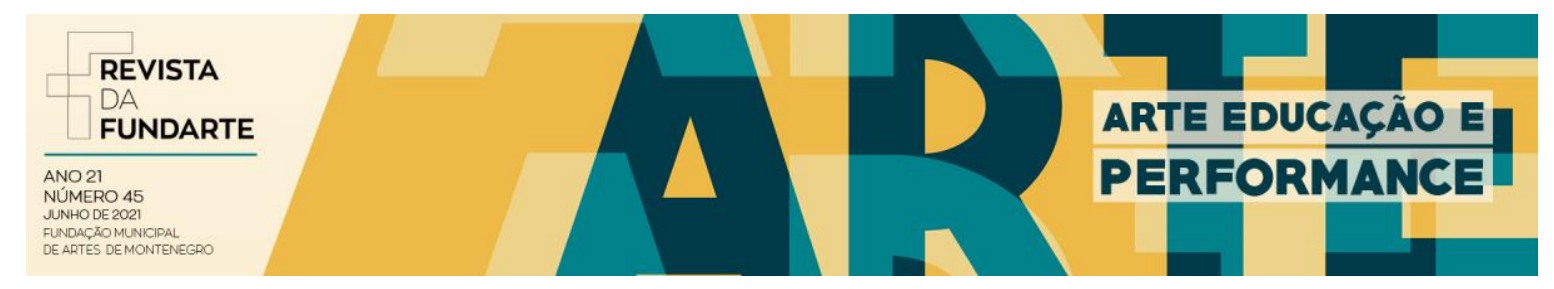

instaura uma estética da fantasmagoria, como antecipação da morte em sua potencialidade visual e transfigurativa.

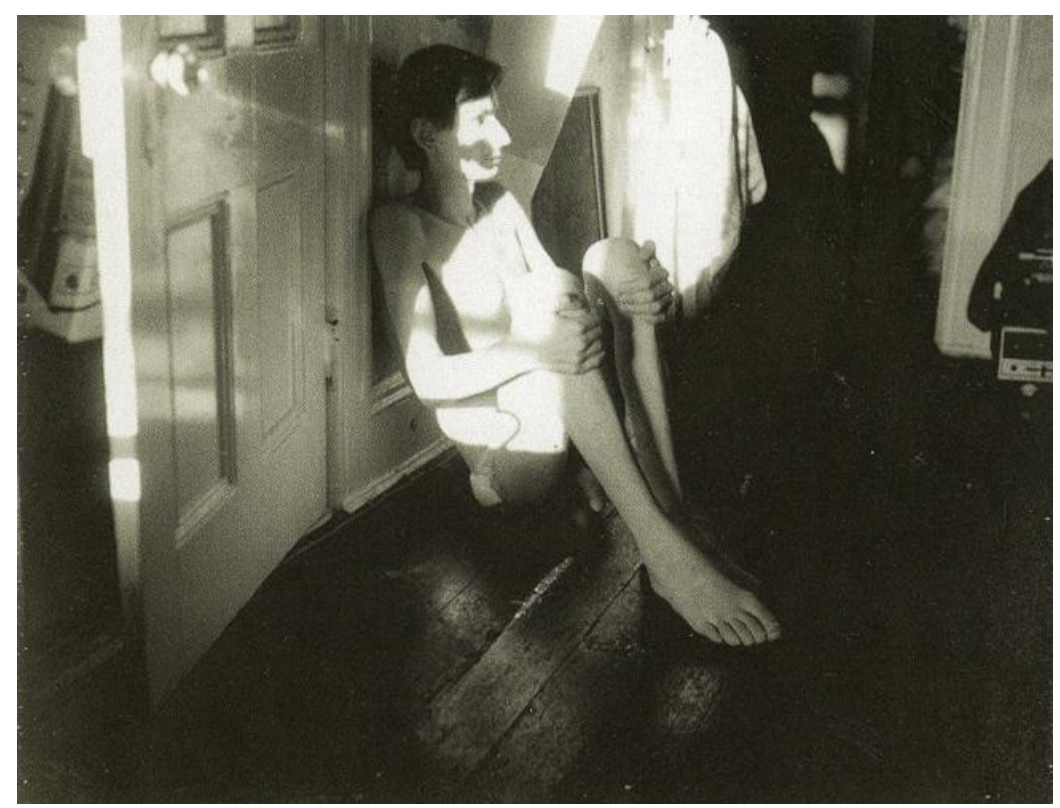

Fig. 3. Mark Morrisroe, Untitled (self-portrait), 1989. Polaroid T-665, 10, 7 × 8,5 cm. Zurique, Suíça. Fonte: JRP Ringier: Catálogo, 2010.

Por fim, a Fig. 4, tirada em plano aéreo, mostra Morrisroe deitado sobre um colchão desfeito, com a cabeça e parte do tronco apoiado em travesseiros, posicionado em um espaço sujo, decrépito e amarfanhado. O fotógrafo já se encontra em seus meses finais de vida. Morrisroe fita de modo oblíquo a lente da câmera, e seu olhar é vago e abstrato. Seu corpo esquelético assume, ao mesmo tempo, uma postura erotizante e alienante, como as figuras longilíneas e esquálidas de Alberto Giacometti. Há um desejo lascivo e flutuante pela morte na imagem, como o próprio olhar do espectador. No entanto, uma ironia relativa à perversidade da doença se instala na imagem: o corpo de Morrisroe aparece surpreendentemente purificado, isto é, sua pele está intacta das lesões escuras e desfiguradoras do sarcoma de Kaposi, câncer raro que atinge doentes terminais de Aids. 

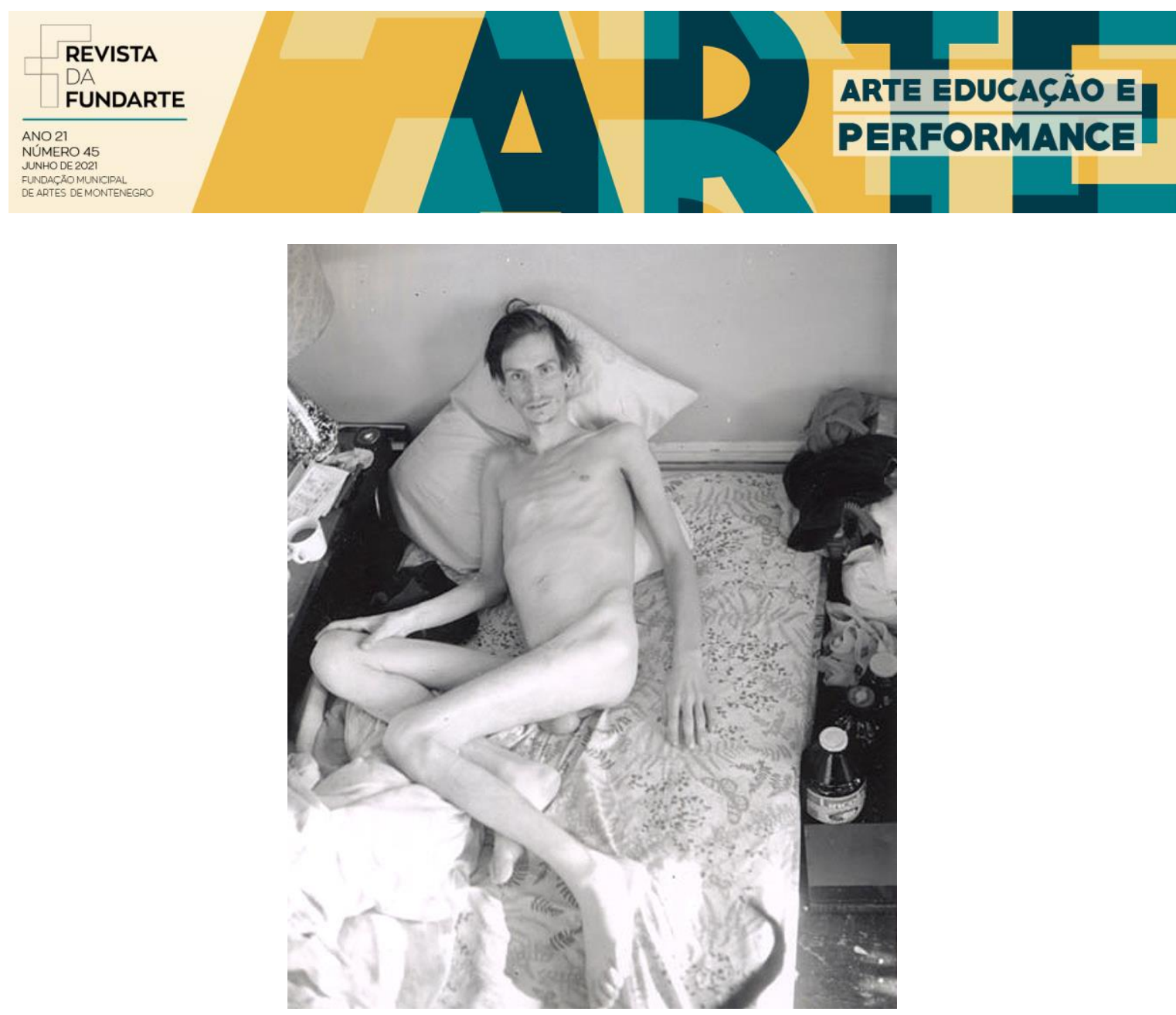

Fig. 4. Mark Morrisroe, Untitled (self-portrait), 1989. Polaroid T-665, 10, 7 × 8,5 cm. Zurique, Suíça. Fonte: JRP Ringier: Catálogo, 2010.

É precisamente nas fotos finais de Morrisroe que o grotesco se manifesta: pela hibridização de erotismo e morte e pelo tensionamento estético entre imagens do artista ainda saudável em oposição ao aspecto cadavérico de seu corpo, articulado a sentimentos de finitude, solidão e estigmatização social. Como um dos grandes artistas que incorporaram o tema da Aids em suas obras - ao lado de Peter Hujar, David Wojnarowicz, Leonilson, Nicholas Nixon, Félix Gonzáles-Torres, entre outros, Morrisroe ressignifica o martírio doloroso e agressivo da doença em experiência estética, testemunho e confissão.

Alves (2016), ao analisar a morfologia visual dos temas da Aids na arte contemporânea, sustenta que a iconografia da doença pode ser divida em três grupos: imagens que tangem à representação do corpo esquelético (o emagrecimento progressivo, como se sabe, é uma das características da síndrome em sua fase terminal), as representações do corpo doente no leito de morte, e 


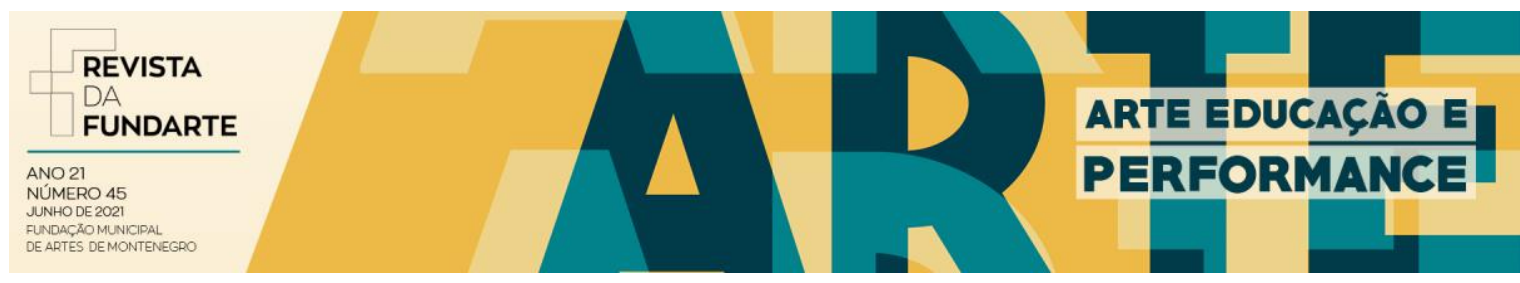

finalmente, a imagética que se desdobra sobre os rituais post mortem, como enterros, túmulos, objetos do falecido, entre outros (ALVES, 2016, p. 3155).

É interessante notar como o corpo esquelético de Morrisroe enceta diálogos visuais com a iconografia tanática do Holocausto judeu e de outras minorias na Alemanha nazista durante a Segunda Guerra Mundial, a partir de imagens de pilhas de corpos esquálidos veiculadas durante a libertação dos campos de extermínio. A seu modo, e de maneira tecnologicamente perversa, a Aids também promoveu seu holocausto particular, atingindo especialmente homens gays que vivenciaram o ápice da liberdade sexual pós-liberação homossexual na década de 1970. Uma doença que deflagrou uma epidemia de metáforas e discursividade punitivista, como definiu Susan Sontag (1986) à época: "Com a Aids, a vergonha vincula-se a uma imputação de culpa. [...] Ter Aids é precisamente ser revelado, na maioria dos casos até o momento, como o membro de uma [...] comunidade de párias" (SONTAG, 1989, p. 24-5, tradução nossa). Para Driscoll (2013),

Quando ele desloca a materialidade de seu corpo para a imagem, Morrisroe a abre para a capacidade de significar, como um objeto - a fotografia como coisa, resistindo à sua condição de moldura transparente ou indexada mas também como sujeito, aquele que é capaz de desejar o corpo que retrata, mesmo quando deve inscrever a ausência e, portanto, a perda desse corpo. [...] Esta qualidade subjetiva parece menos saliente nas polaroids [...] um eco erótico que reverbera pela presença de Morrisroe como artista e tema que atravessa as fotografias. (DRISCOLL, 2013, p. 356 , tradução nossa).

O grotesco, em Morrisroe, emerge gradualmente - como o próprio período latente da Aids nos corpos - no modo como seu corpo saudável se transubstancia na imagem desorientadora de um corpo doente, em definhamento, relegado aos espaços periféricos do abandono, tão familiares a muitos homens gays que adoeceram pela doença nos anos 1980 e 1990. A beleza chocante e grotesca da Fig. 4 reside justamente nessa recusa de Morrisroe em infantilizar o espectador diante da imagem: está tudo ali, ainda que implicitamente: o emagrecimento, a febre alta constante, a diarreia, os gânglios inflamados e problemas respiratórios. Morrisroe, atualizando a experiência romântica da morte prematura nos espaços 


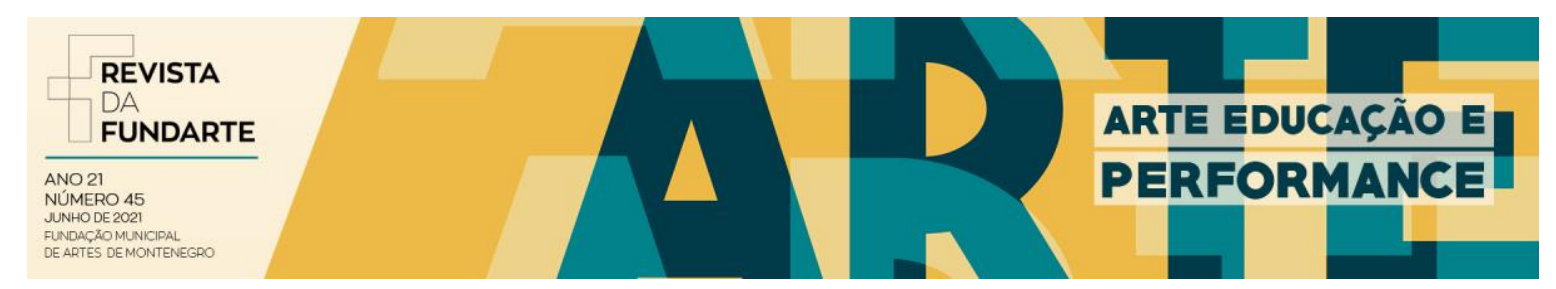

decrépitos das metrópoles e na liberdade gay pós Stonewall, fez de sua vivência limítrofe o material plástico com que fundamentou suas obras.

\section{O CORPO PENETRÁVEL DE ROBERT MAPPLETHORPE}

Engendrada em 1978, a série de fist fuckings constitui-se, provavelmente, como o trabalho mais transgressor de Robert Mapplethorpe, tanto de uma perspectiva puramente imagética - a representação do fist fucking, isto é, a práxis da penetração sexual pelo punho ou braço, no caso, entre dois homens - quanto de um ponto de vista político, já que o ato, além de subverter os parâmetros normativos das heterossexualidades e homossexualidades, que estabelecem a penetração como possível apenas entre órgãos genitais, ainda desafia os códigos morais vigentes, em especial no puritanismo da sociedade americana. Para fins deste artigo, selecionamos quatro fotografias da série que documentam e estetizam a prática, imagens praticamente gêmeas, mas que possibilitam leituras distintas.

Fist fuck/ double (Fig. 5) apresenta, em padrão quase simétrico, dois braços sendo introduzidos em um ânus masculino, que aparece apoiado no encosto de uma cadeira leather. Mapplethorpe elimina os resíduos humanos da imagem, isto é, o corpo dos atores envolvidos na ação, e fundamenta o fist fucking em close, o que imediatamente resvala para uma apreciação abstrata, irracional, quase dadaísta da imagem. Se estabelece também uma tensão entre as linhas arredondadas (as nádegas masculinas) e as linhas retas e angulosas da composição (o encosto da cadeira, o ângulo de 90 graus do braço direito que aparece na imagem). 

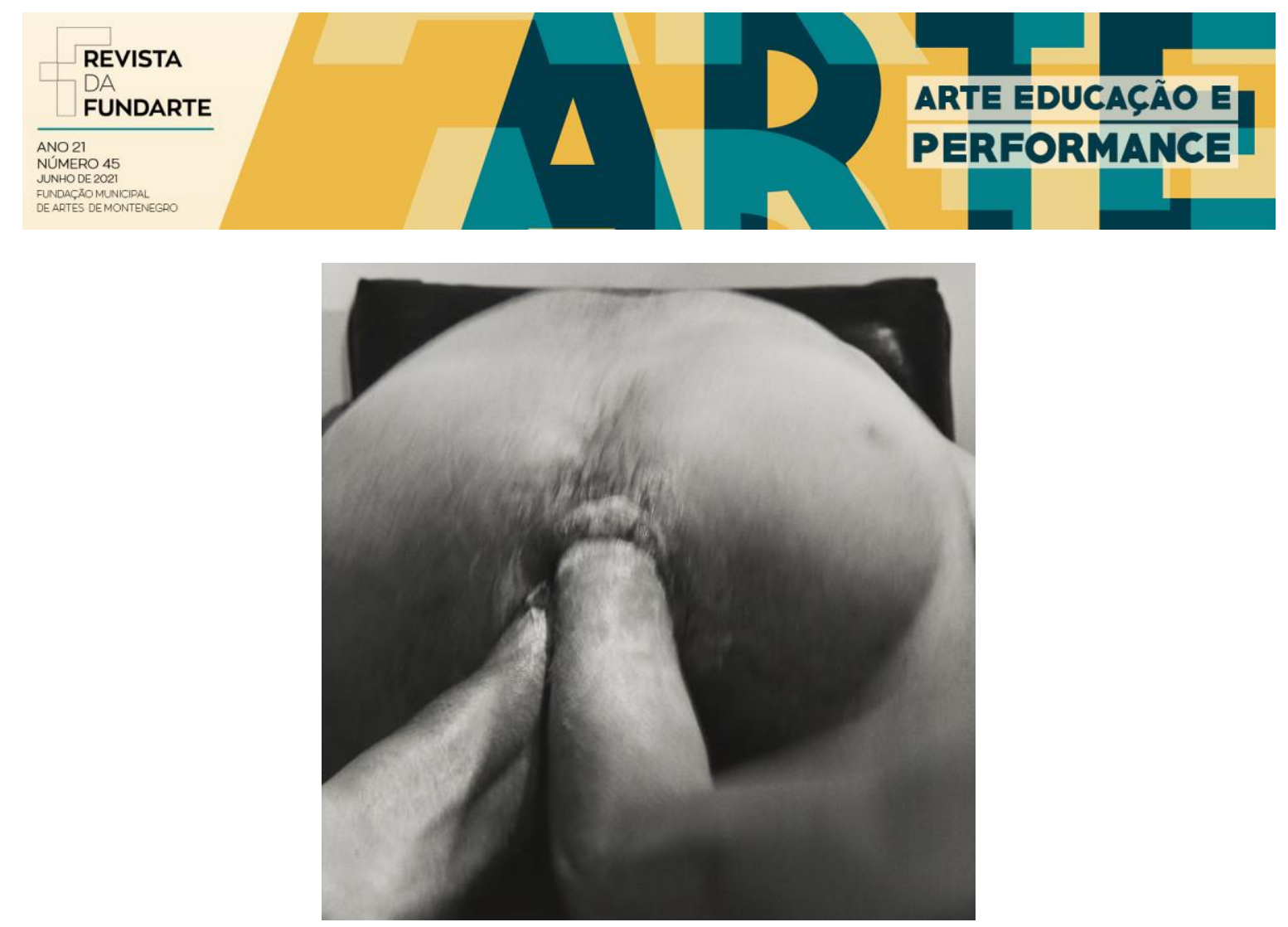

Fig. 5. Robert Mapplethorpe, Fist fuck/ double, 1978.

Gelatin silver print. 50, $8 \times 40,6 \mathrm{~cm}$. New York, NY.

https://www.alisonjacquesgallery.com/exhibitions/141/works/artworks9630/

A segunda imagem (Fig. 6), bastante similar à primeira, focaliza com maior acuidade e em maior close-up a imagética agressiva do fist fucking. A partir de tal opção estética, mais uma vez abstrai-se a imagem humana dos atores penetrantes na ação e as nádegas do penetrado, para a figuração de um esfíncter sendo alargado e prolapsado enquanto dois antebraços disputam a cavidade retal. Logo abaixo dos braços, a bolsa escrotal do penetrado imbui verticalidade à imagem, como um pêndulo, enquanto o anel escrotal estrangulando os testículos agrega sentidos de animalidade à composição. Os dois braços encontram-se besuntados de um líquido lubrificante e líquidos prostáticos liberados pelo penetrado durante o empalamento. 

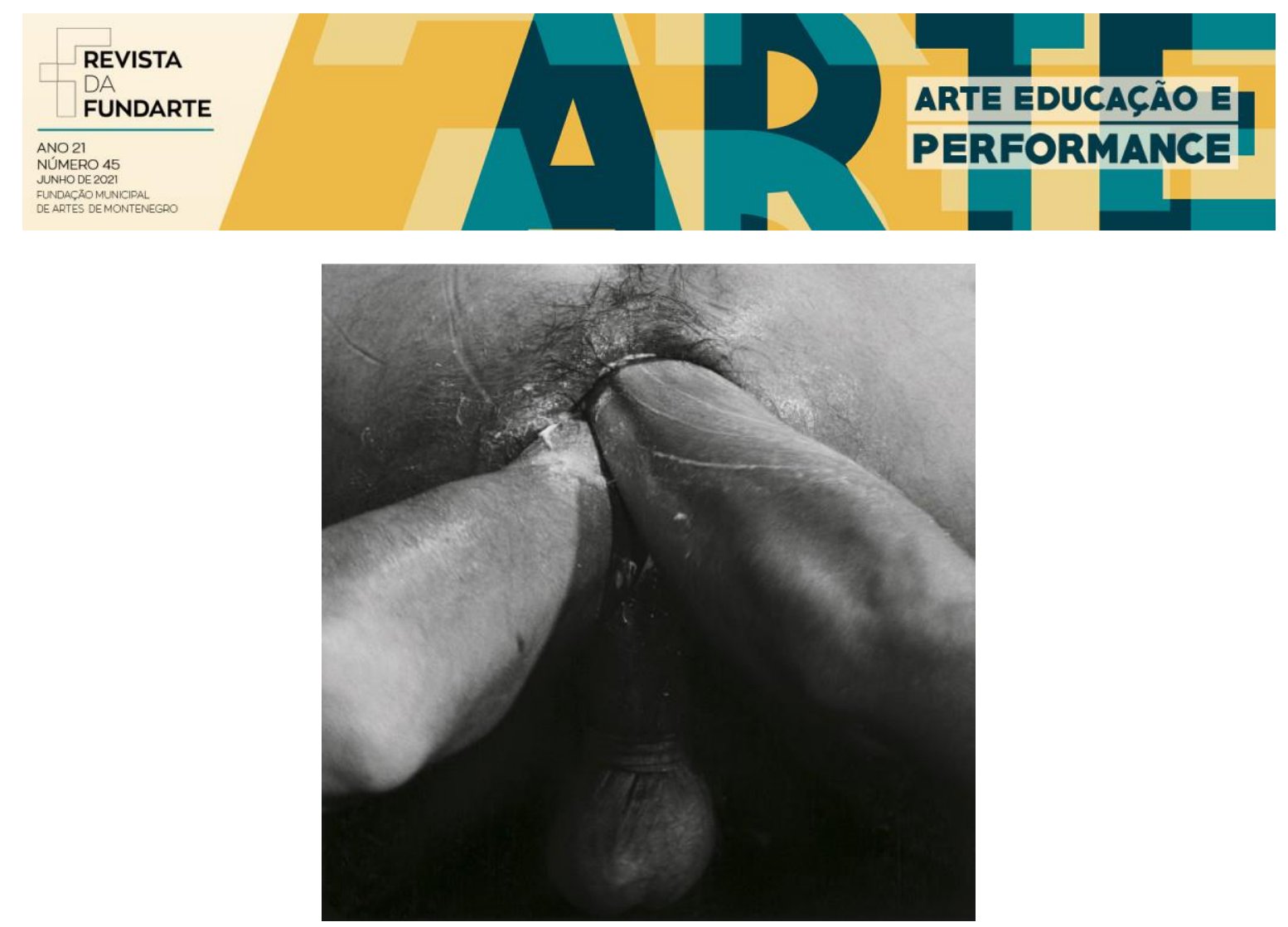

Fig. 6. Robert Mapplehorpe, Double fist fuck, 1978.

Gelatin silver print, 35, 2 × 35, $1 \mathrm{~cm}$. New York, NY. https://www.phillips.com/detail/robert-mapplethorpe/UK000110/96

O grotesco, nos fist fuckings de Mapplethorpe, manifesta-se a partir da abstração primitiva da imagem, possibilitada pela forma da obra em si: ao posicionar a câmera em close no objeto - ela mesma como se desejasse penetrar o orifício fétido e antitético da cultura (SAEZ \& CARRASCOSA, 2016), - abstrai-se imediatamente as formas humanas que tomam parte na ação, e vê-se apenas a imagem de dois braços penetrando um orifício alargado, a bolsa escrotal alongada e subjugada por um anel peniano fetichista. Como duas naturezas-mortas do abjeto, os componentes da imagem estabelecem uma relação triangular e anômala, desorientando o espectador. Além disso, o grotesco manifesta-se, aqui, a partir de dois viés semânticos: ao mesmo tempo em que se visualiza a liturgia da penetração anal por dois braços, observa-se também um processo de amputação desses braços, engolidos pela cavidade retal do penetrado. Ou, num movimento exógeno, o reto do penetrado parece expelir monstruosamente os dois braços, numa imagética disforme, tangente ao escatológico.

As Figs. 7 e 8, por sua vez, mostram a prática do fist fucking em sua representação completa. Ambas parecem ocorrer em um mesmo local, quando se 


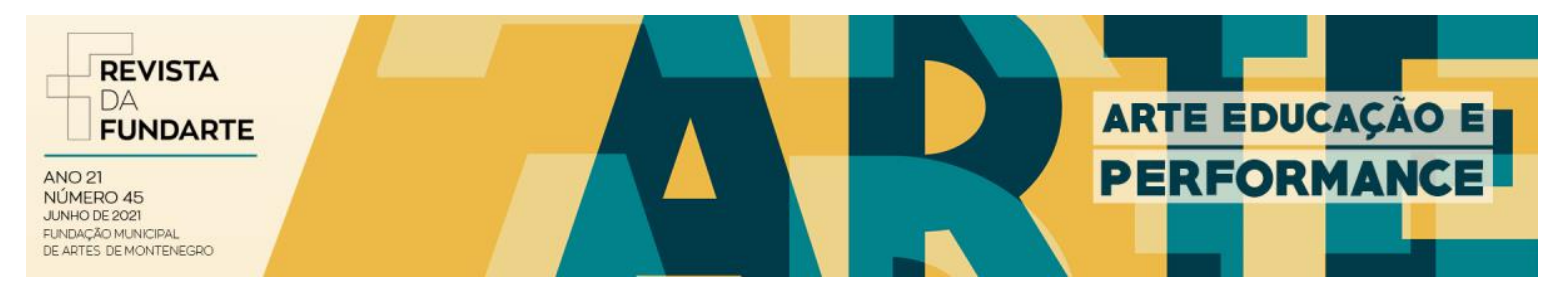

observa as características do ambiente, e mostram dois atores envolvidos na performance. Ambos estão de costas para o fotógrafo e o espectador, a fim de ressaltar o pathos subterrâneo da prática na hierarquização de uma scientia sexualis que prescreve a penetração pênis versus orifícios (vagina, ânus, boca) a partir de uma (hétero) normatividade.

Na primeira imagem, Helmut fist fuck (Fig. 7), o penetrador aparece nu, sentado, penetrando o ânus do passivo enquanto apoia a mão esquerda no chão. Os coturnos e o adorno de couro no pulso são indícios de que estamos inseridos no cosmo underground da prática leather e BDSM. O penetrado, por sua vez, aparece com o corpo subjugado, em um ângulo de 90 graus, e, enquanto é penetrado, se masturba, a mão direita posicionada logo abaixo dos testículos. A segunda imagem, Fist fuck/full body (Fig. 9), por sua vez, segue a ritualística visual da primeira, exceto que o penetrador aparece em posição inclinada, com o torso nu e trajando apenas calça jeans, enquanto penetra todo o antebraço na cavidade anal do ator passivo, cujos braços aparecem dispostos simetricamente sobre o espaldar da cadeira.

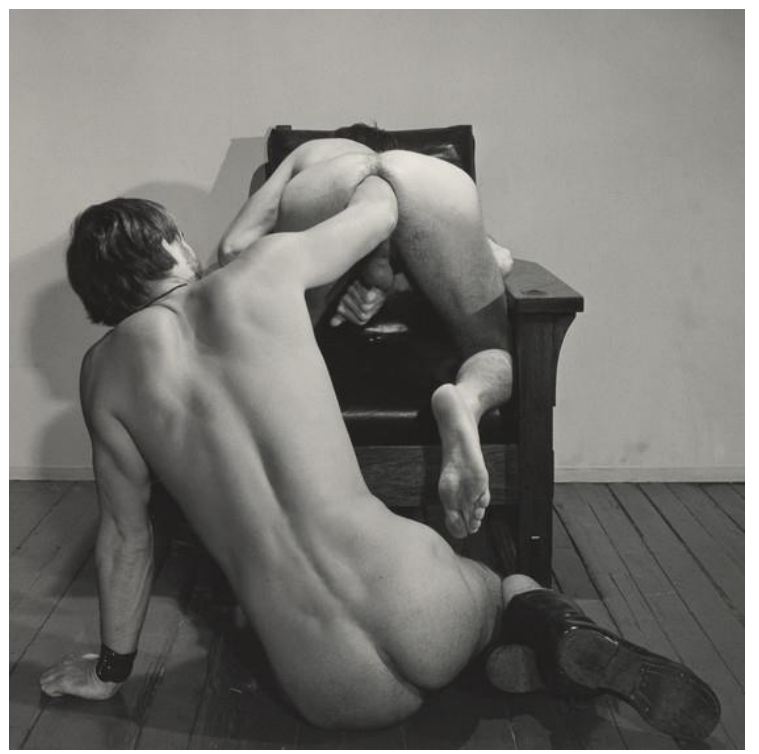

Fig. 7. Robert Mapplethorpe, Helmut fist fuck, 1978. Gelatin silver print, 35, $2 \times 35,2 \mathrm{~cm}$. New York, NY. https://collections.lacma.org/node/2233391 

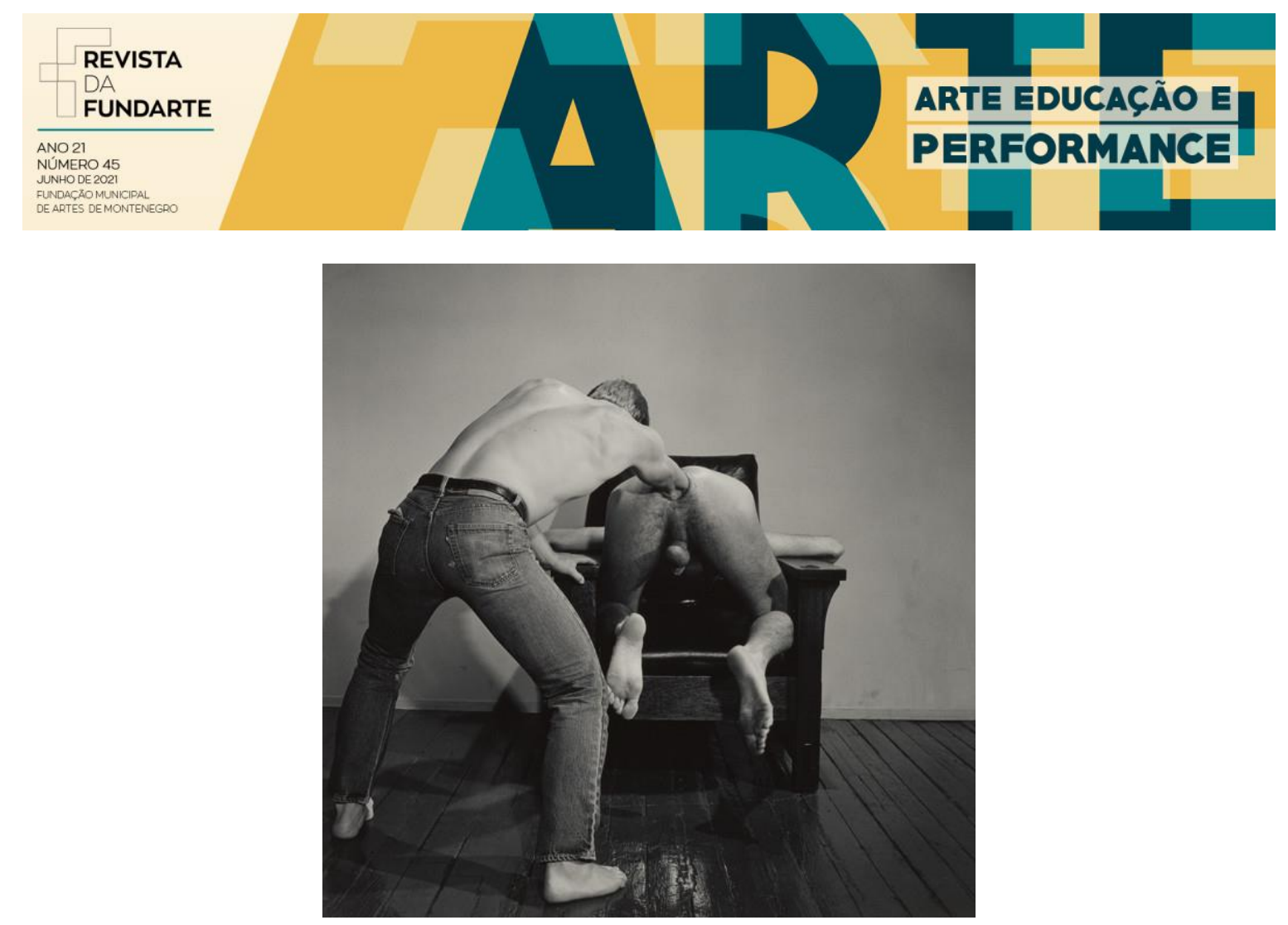

Fig. 8. Robert Mapplethorpe. Fist fuck/ full body, 1978, Gelatin silver print, $35 \times 35 \mathrm{~cm}$. New York, NY. https://collections.lacma.org/node/2233389

É interessante observar como os dois penetradores buscam manter o equilíbrio físico no momento da prática: o primeiro apoia a mão esquerda no chão, e o segundo fista o companheiro em pé, enquanto apoia a mão direita nos braços da cadeira - quase como se, inconscientemente, eles revivessem um medo arcaico de serem tragados pelo abjeto, por uma escatologia que é, ao mesmo tempo, sagrada afinal, se Deus está em todas as coisas, ele também está no cu, como postula o poeta capixaba Valdo Motta: "Ó Deus serpentecostal/ que habitais os montes gêmeos/ e fizeste do meu cu/ o trono do vosso reino" (MOTTA, 1996, p. 45).

Nestas imagens, o grotesco exsuda-se da estruturação palimpsêstica de sentidos: a identidade anônima dos envolvidos, a representação do baixo corporal, a ressignificação plástica e esperpêntica da mecânica normativa da penetração, além da agressividade que a imagem suscita. Segundo Brintnall (2011),

Estas imagens não se referem apenas a uma auto-representação gay masculina ou uma apologia a dedeterminados atos. Em vez disso, elas valorizam o abjeto. A despeito do quanto a espectadora ou espectador reconheçam a si mesmos nessas práticas particulares e desejos 


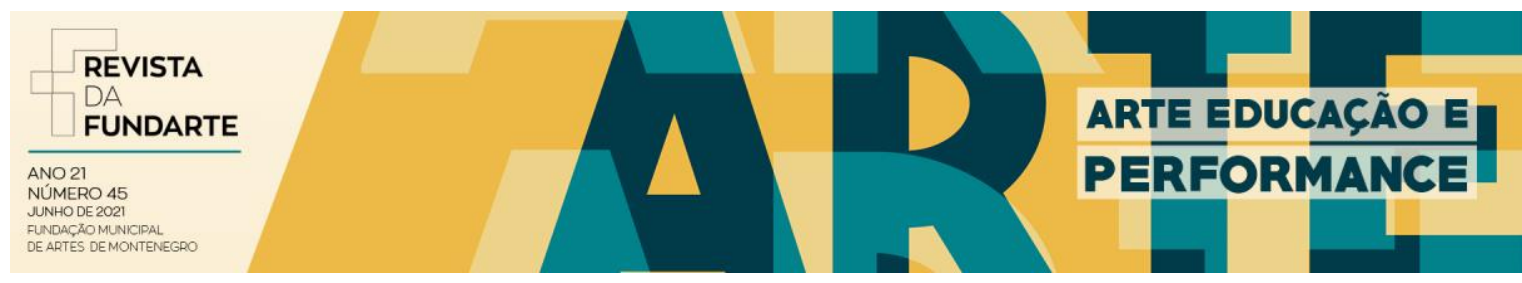

específicos, as imagens trazem o marginal para o centro e o invisível para o espaço público. A revelação e glorificação disso, que tem sido escondida, demonizada e degradada é significativa para uma gama de subjetividades subalternizadas. Mais importante, tais imagens oferecem um aparato crítico para que se vejam representações culturais da subjetividade masculina e do desejo homoerótico de maneira diferente. (BRINTNALL, 2011, p. 115, tradução nossa).

Bakhtin (1987) postula que uma das características da imagem corporal do grotesco consiste em "exibir dois corpos em um: um que dá a vida e desaparece, e outro que é concebido e lançado ao mundo. [...] Do primeiro se desprende sempre, de uma forma ou outra, um corpo novo" (BAKHTIN, 1987, p. 23, grifo do autor). É exatamente a imagem da junção de corpos que se apresenta neste fist fucking de Mapplethorpe: a dualidade grotesca de gêmeos xipófagos unidos pela analidade. Nos fist fuckings, há o tensionamento semântico da penetração braço - símbolo exterior do trabalho, da civilização, da cultura e da arte - versus ânus, como metáfora permanente do que há de mais sórdido no sentido corporal, ou, nos termos de Sáez \& Carrascosa (2016),

O cu é o grande lugar da injúria, do insulto. Como vemos em todas essas expressões cotidianas, a penetração anal como sujeito passivo está no centro da linguagem, do discurso social, como o abjeto, o horrível, o mal, o pior. Todas essas expressões traduzem um valor primordial, unânime, generalizador: ser penetrado é algo indesejável, um castigo, uma tortura, um ato odioso, uma humilhação, algo doloroso; é a perda da honra, algo

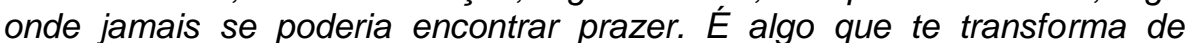
maneira essencial. A partir desse ato, você "é" é um fodido pelo cu, um enrabado, uma bicha. (SÁEZ \& CARRASCOSA, 2016, p. 27, grifo nosso).

Nestes fist fuckings, Mapplethorpe fratura a parede espessa que delimita o espaço público e o olhar decorrente dele, a partir dos rituais privados de práticas sexuais menos ortodoxas. Na plasticidade destas imagens, instaura-se uma fissura reveladora, algo voyeurística e pluridimensional em que todos são permitidos espiar, constituída pelo olhar do fotógrafo, o olhar do espectador, o olhar do penetrador, 0 olhar do penetrado, o olhar da tradição, o próprio esfíncter e ânus dilacerados que 


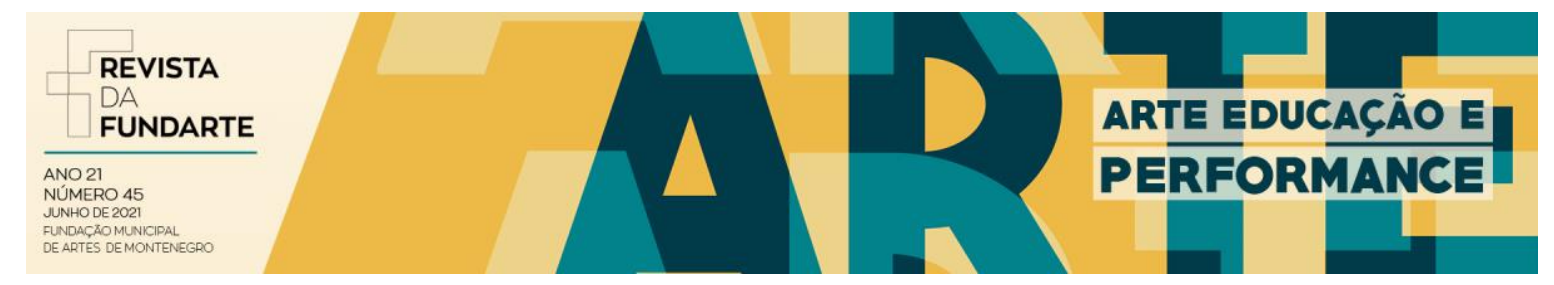

nos olham - todos enredados em uma fenomenologia primitiva e transgressora, e, exatamente por isso, tão referente a nós mesmos.

\title{
4. O CORPO MUTILADO DE RUDOLF SCHWARZKOGLER
}

Expostas pela primeira vez na Alemanha entre junho e outubro de 1972 (PECORELLI, 2019, p. 74), estas fotografias de Rudolf Schwarzkogler assenta-se na representação de um conjunto de performances (ou aktions), realizadas entre 1965 e 1966, com o auxílio de Heinz Cibulka, amigo do artista e modelo que aparece nas imagens. Como já assinalamos, Schwarzkogler integrava a escola radical dos Acionistas vienenses, cujas performances, fotografias e vídeos baseavam-se em

\begin{abstract}
Imagens de corpos despidos, travestidos, bestiais, sacrílegos, que defecam, urinam, que comem fezes, que bebem urina, que se masturbam publicamente, vomitam, debocham de símbolos nacionais, blasfemam o catolicismo, sincretizam tradições míticas, encenam orgias e práticas sadomasoquistas, destroem objetos, sacrificam animais, enfim, toda essa imaginação acionista - no sentido de uma intensa produção de imagens tão sacrificiais quanto eróticas - [articulando] no campo da arte e para além dele, uma das críticas ao projeto humanista e civilizatório mais impactantes que a arte do século XX conheceu. (PECORELLI, 2019, p. 20).
\end{abstract}

Desse modo, pretende-se analisar o modo como o grotesco imiscui-se em quatro imagens selecionadas das aktions de Schwarzkogler, mais especificamente as Aktion 2 e 3, a partir de uma abordagem essencialmente imagética, sem nos atermos às complexidades ritualísticas da performance per se.

A Fig. 9 apresenta uma pélvis masculina em close, as coxas abertas formando uma triangulação sobre a superfície na qual está apoiada (um lençol branco). Heinz Cibulka aparece sentado sobre uma grande esfera branca, ovoide, a partir da qual emerge um grande peixe escuro, aparentemente morto, com a bocarra aberta e as guelras úmidas coladas graciosamente à virilha do modelo. Trata-se de uma imagem de grande instabilidade semântica, calcada em uma multiplicidade de significados, justamente pela heterogeneidade dos elementos que a compõe. A 


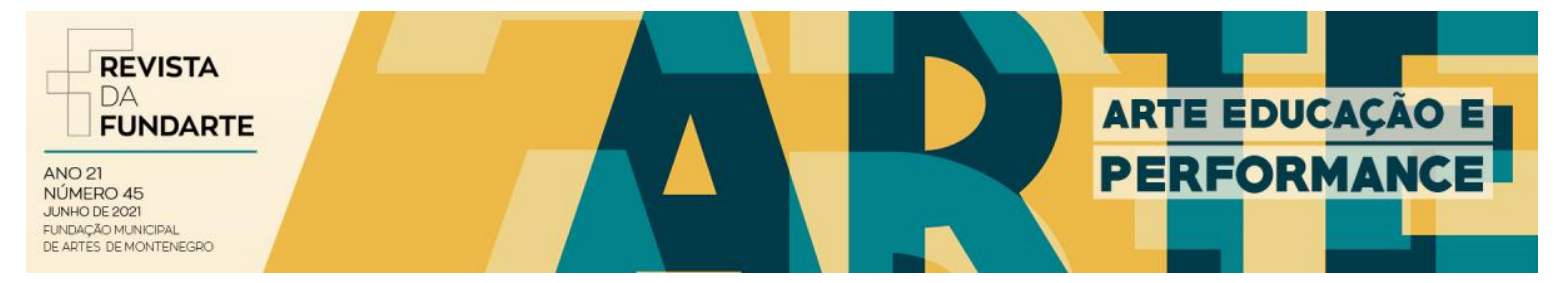

grande esfera branca, simulando um ovo, pode ser inferida tanto como significante substitutivo da bolsa escrotal de Cibulka, quanto uma referência aos óvulos femininos, à maternidade e à gênese. O peixe, por sua vez, sugere Archer (2012), pode ser "sugestivo tanto de pênis mutilado como de vagina aberta, o simbolismo do peixe solapa a integridade ou inteireza do senso de integridade do performer, o eu substituto de Schwarzkogler" (ARCHER, 2012, p. 111). É importante ressaltar que o pênis do modelo está inserido no peixe, numa espécie de sodomia paródica e zoofílica.

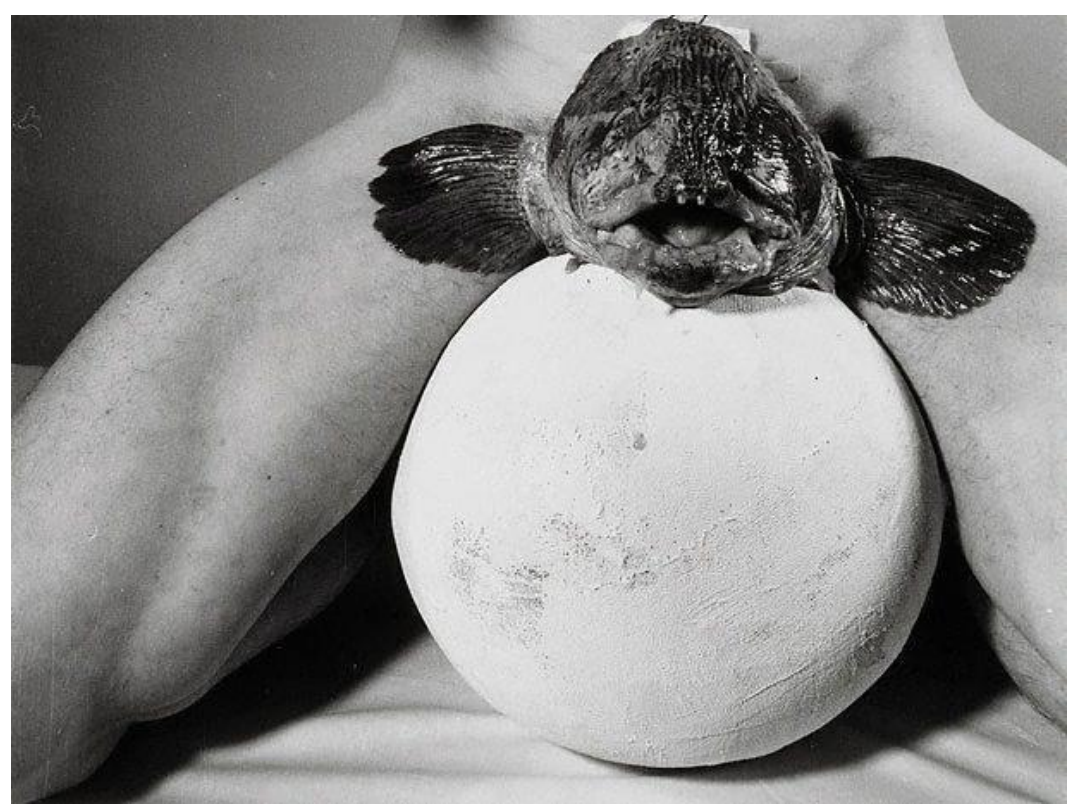

Fig. 9. Rudolf Schwarzkogler, Aktion 2, 1965. Viena, Áustria. Foto: Ludwig Hoffenreich.

Tal imagem parece encetar uma narrativa, quando observada ao lado da Fig. 10. Esta apresenta uma estrutura semelhante - a mesma pélvis sentada sobre um ovo, dessa vez enfaixada por gazes, como se tivesse passado por uma cirurgia recente. Um par de mãos (provavelmente as de Schwarzkogler), que remetem às de um médico, eviscera o peixe com uma faca rudimentar. A pélvis de Cibulka aparece manchada de sangue nas duas laterais, enquanto o modelo aparenta estar com as mãos atadas às costas. 

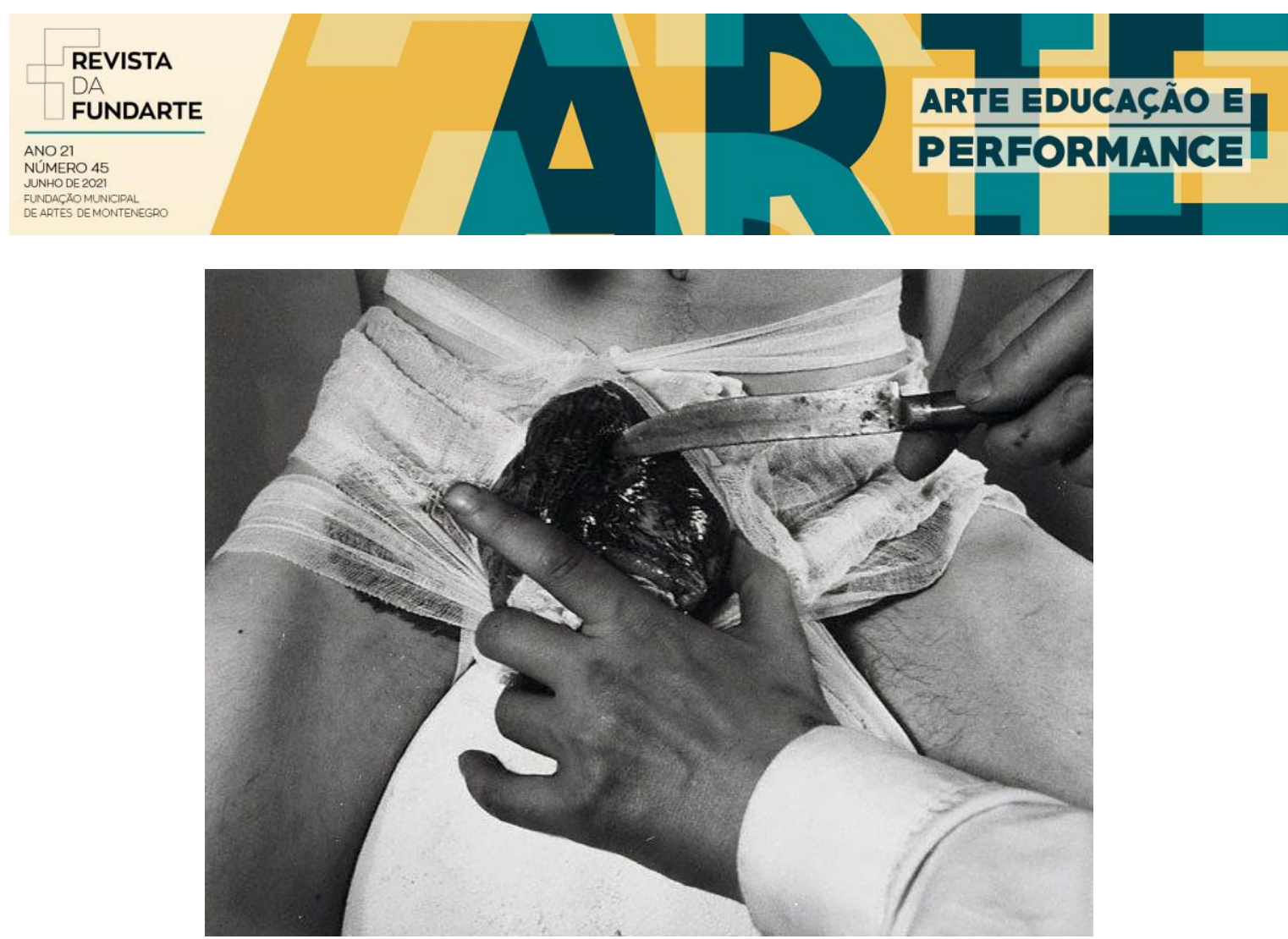

Fig. 10. Rudolf Schwarzkogler, Aktion 2, 1965.

Viena, Áustria. Foto: Ludwig Hoffenreich.

A Fig. 11 é menos elíptica em seus semas de castração. Nela, a pélvis de Cibulka está diante de uma chapa negra, que simula uma bandeja de instrumentos cirúrgicos, na qual estão dispostas algumas lâminas, à esquerda, e duas tesouras e uma seringa, à direita. $\mathrm{O}$ modelo repousa o pênis enfaixado sobre a pequena mesa cirúrgica, os pelos pubianos escuros contrastando com o branco da gaze. Uma circuncisão ou auto-mutilação parece ter ocorrido. Além disso, um escorpião em miniatura, de plástico, toca suavemente, com suas garras, o membro suturado e enfaixado. Finalmente, a Fig. 12 parece referir-se a um estado pós-operatório, no qual Cibulka aparece completamente enrolado em panos mortuários, deitado sobre um colchão estreito, em uma posição esdrúxula e performática. Além da gaze, há em seu corpo uma profusão de fios, amontoados entre o tórax e o braço esticado. A morbidez da imagem é ressaltada pelos lençóis brancos e pela corporalidade de Cibulka, que parece, ao mesmo tempo, inerte e alerta. 


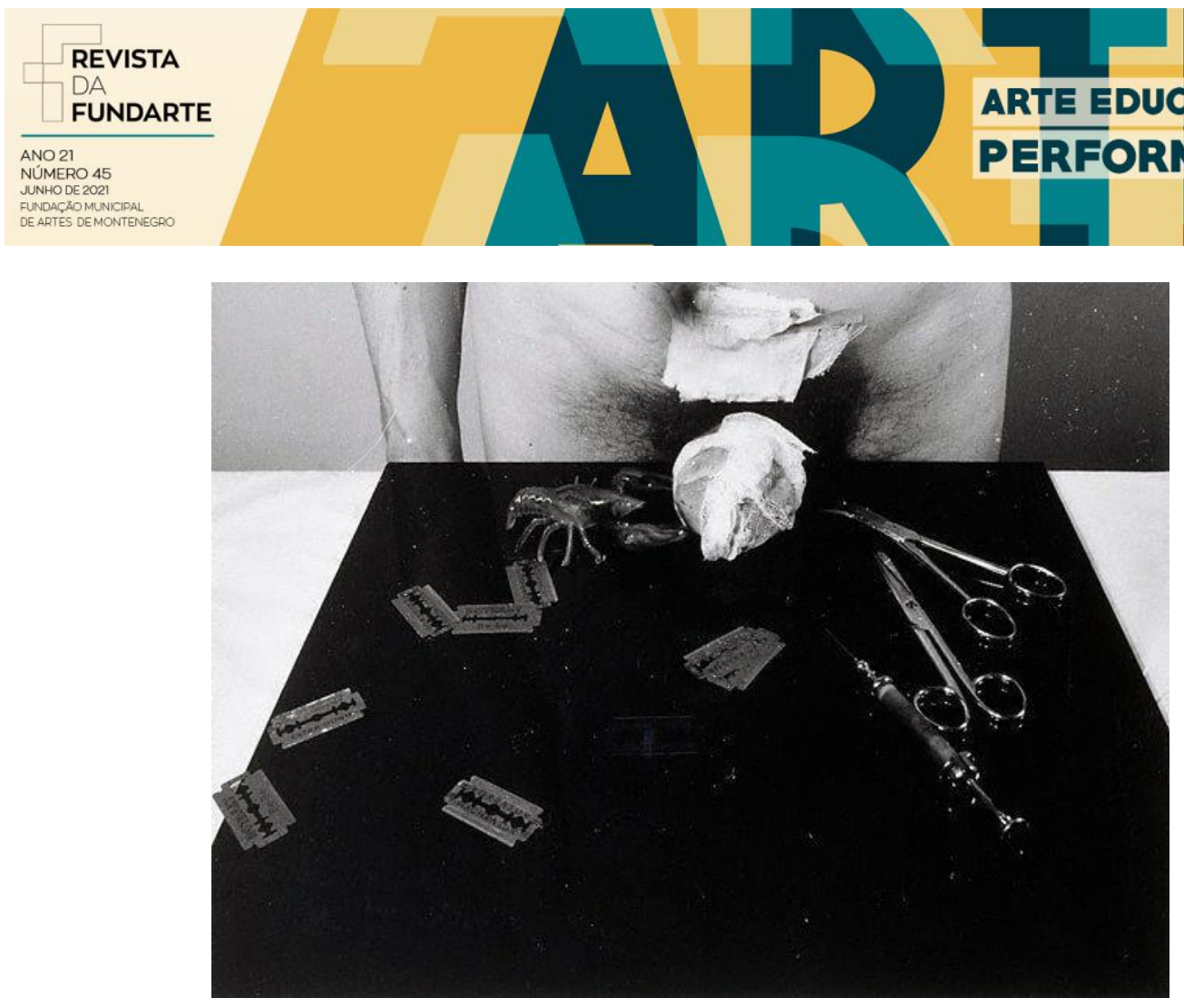

Fig. 11. Rudolf Schwarzkogler, Aktion 2, 1965. Viena, Áustria. Foto: Ludwig Hoffenreich.

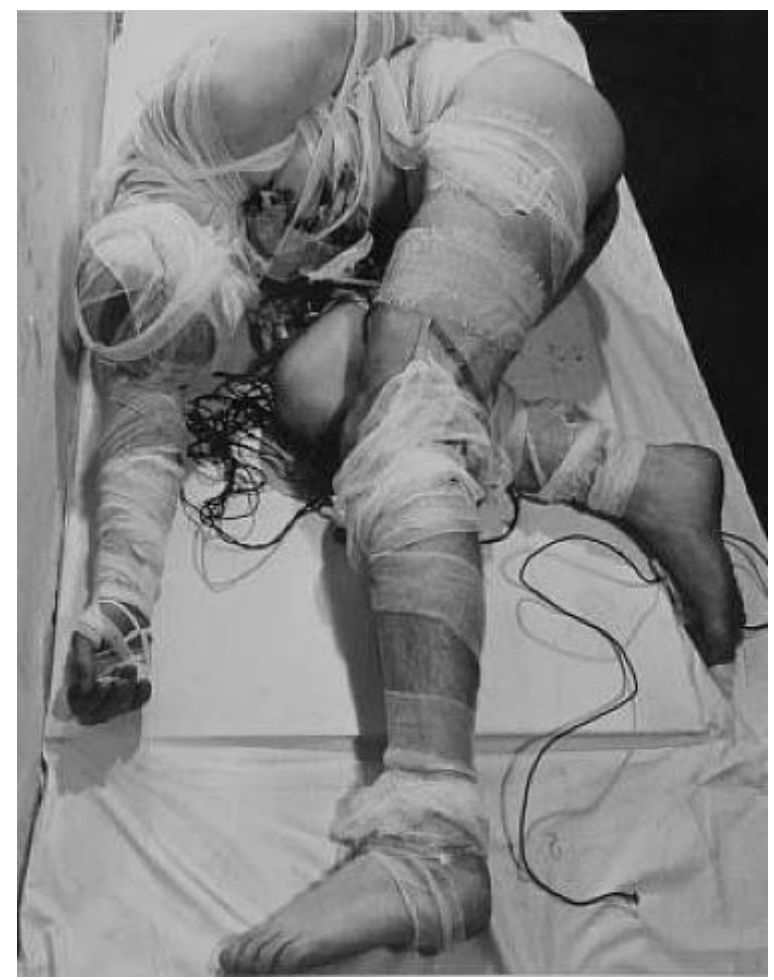

Fig. 12. Rudolf Schwarzkogler, Aktion 3, 1965. Viena, Áustria. Foto: Ludwig Hoffenreich.

SILVA, Claudimar Pereira. Manifestações do Grotesco em Mark Morrisroe, Robert Mapplethorpe e Rudolf Schwarzkogler. Revista da FUNDARTE. Montenegro, p.01-26, ano 21, № 45, junho de 2021. Disponível em: http://.seer.fundarte.rs.gov.br/index.php/revistadafundarte/index> 30 de junho de 2021. 


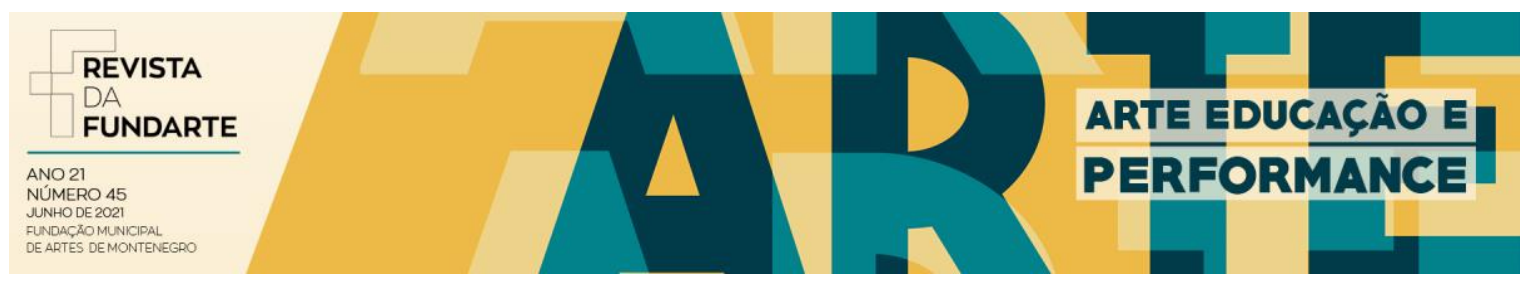

Nestas imagens, o grotesco se manifesta como fantasias de castração e mutilação, que podem referir-se tanto a rituais de circuncisão de povos específicos do brit milá judaico ao ulwaluko da etnia xhosa, na África do Sul - quanto uma possível referência à angústia masculina arcaica de dessexualização por meio da extirpação do pênis. Trata-se de um sistema simbólico de elementos discrepantes, enfeixados numa semântica que abrange questões referentes à violência, à masculinidade e às pulsões destrutivas da civilização. De acordo com Pecorelli (2019), as imagens de auto-castração de Schwarzkogler operam como "formas materiais de questionar o Pai (a Ordem, a Lei), diluir as fronteiras de gênero num caudal orgiástico ou ainda rebaixar o corpo humano a um acintoso bestiário" (PECORELLI, 2019, p. 87-8, grifo nosso).

Se, para Bataille (2017), "Entre um ser e outro, há um abismo, há uma descontinuidade" (2017, p. 36), ou seja, os indivíduos constituem-se como seres descontínuos, saudosos de uma continuidade perdida com o nascimento e que é resgatada pelo erotismo, pelo desejo de continuidade - logo, os processos de automutilação de Schwarzkogler podem ser considerados como uma tentativa ritual, estilizada e performativa de descontinuar (cortar, filetar, rasgar) na própria descontinuidade corporal e ontológica, como veículo de obtenção de alguma verdade relativa ao caráter transfigurativo da arte. Schwarzkogler, assim, na estrutura da performance, descontinua seu corpo já descontinuado, a fim de que uma dimensão mística seja atingida. No caso, ressignificando o postulado de Bataille sobre a questão do sacrifício ritual, quando a pele de Schwarzkogler é cindida por uma lâmina, ela revela algo do qual artista e espectador participam: o sagrado (BATAILLE, 2017, p. 45).

A morte de Schwarzkogler, mitologizada no mundo da arte conceitual como tendo sido causada por um desses rituais de auto-mutilação, porém desmentida por estudiosos que ressaltam que sequer é o artista que aparece nas imagens, e sim Heinz Cibulka, ocorreu em 1969, quando Schwarzkogler, sofrendo problemas psiquiátricos, se joga do segundo andar de seu apartamento em Viena (PECORELLI, 2019, p. 93). Ou cai da janela de seu apartamento, emulando a 


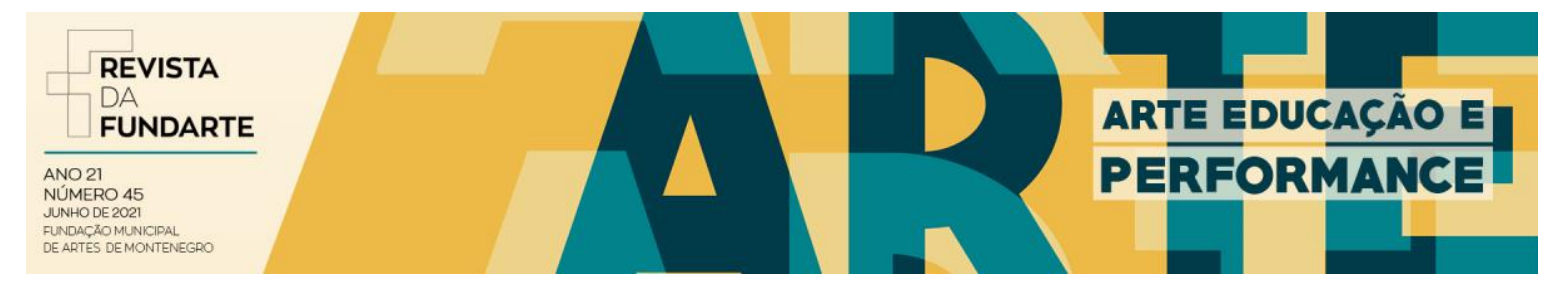

poética da queda de um Bas Jan Ader (1942-1975), como ato performativo final em direção ao vazio.

\section{CONSIDERAÇÕES FINAIS}

Bakhtin (1987), em estudo já mencionado sobre Rabelais, estabelece o conceito de corpo grotesco. Para o teórico russo, os padrões de beleza valorativos e sancionados pela ordem vigente estão pautados na ideia de um corpo acabado, fechado, hermético, consciente de seus moldes e de seus limites, sendo que "tudo o que sai, salta do corpo, isto é, todos os lugares onde o corpo franqueia seus limites e põe em campo um outro corpo, destacam-se, eliminam-se, fecham-se, amolecem" (BAKHTIN, 1987, p. 280). Esta estrutura acabada, fechada, monológica (num sentido corpóreo), rejeita "todos os orifícios que dão acesso ao fundo do corpo", e "encontra-se na base da imagem a massa do corpo individual e rigorosamente delimitado: a sua fachada maciça e sem falha" (1987, p. 280, grifo nosso).

O corpo grotesco, por sua vez, manifesta-se poroso, desagregado de suas formas idealizadas e bem acabadas, abrindo-se para o mundo exterior, "onde $o$ mundo penetra nele ou dele sai ou ele mesmo sai para o mundo, através de orifícios, protuberâncias, ramificações e excrescências, tais como a boca aberta, os órgãos genitais, seios, falo, barriga e nariz' (BAKHTIN, 1987, 23, grifo nosso).

Diante disso, não há nada mais grotesco do que os corpos que andarilham pelas poéticas contestadoras de Morrisroe, Mapplethorpe e Schwarzkogler. Na obra desses três artistas malditos, três cérberos que guardavam as portas do submundo gay urbano, efervescente e pulsional que pulula sob as regras de uma falsa civilidade, há uma profusão de corpos doentes e esquálidos, esquartejados, abertos e penetráveis, pênis mutilados, ânus prolapsados e esfíncteres alargados - a fragilidade ôntica e a abertura grotesca do corpo está dada, eviscerada, em suas poéticas. Tais componentes são levados aos limites de expansão em nome da práxis de um ideal de arte que retira sua potencialidade avant-garde da 


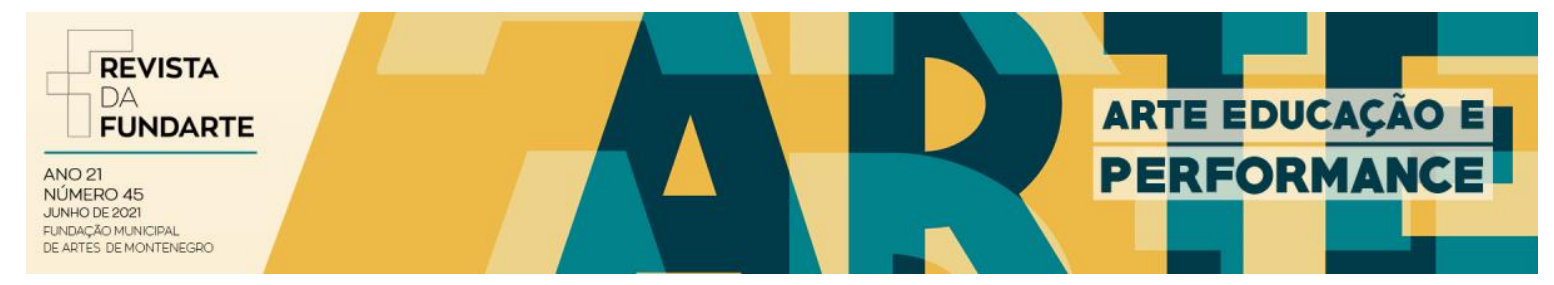

representação do disforme, do anômalo e do inquietante, escondido debaixo de nossas camas, atrás de nossas portas e armários.

\section{Referências:}

ALVES, R. H. A. Considerações sobre arte, morte e fotografia em tempos de Aids. Trabalhos completos. 25. Encontro da ANPAP. Porto Alegre, RS, 2016. p. 31503164.

ARCHER, M. Arte contemporânea: uma história concisa. Trad. Alexander Krug e Valter Lellis Siqueira. 2. ed. São Paulo: Editora WMF Martins Fontes, 2012.

BAKHTIN, M. A cultura popular na ldade Média e Renascimento: o contexto de François Rabelais. Trad. Yara Frateschi Vieira. São Paulo - Brasília: Editora da Universidade de Brasília, 1987.

BATAILLE, G. O erotismo. Trad. Fernando Scheibe. 1. ed. Belo Horizonte: Autêntica Editora, 2017.

BRINTNALL, K. L. Ecce homo: the male-body-in-pain as redemptive figure. Chicago, IL: University of Chicago Press, 2011.

DIDI-HUBERMAN, G. O que vemos, o que nos olha. Trad. Paulo Neves. 2. ed. São Paulo: Editora 34, 2010.

DRISCOLL, M. P. The desiring photograph: Mark Morrisroe's bodily self-portraits. Masters dissertation. University of California, Los Angeles, 56 f. 2013.

KAYSER, W. O grotesco: configuração na pintura e na literatura. Trad. J. Guinsburg. São Paulo: Perspectiva, 1986.

MOTTA, V. Encantamento. In: Bundo e outros poemas. Campinas, SP: Editora Unicamp, 1996.

PECORELLI, B. Poéticas do sacrifício 1960-1978: excesso e martírio na arte da performance à luz dos escritos de Bataille e do Acionismo de Viena. Tese de 


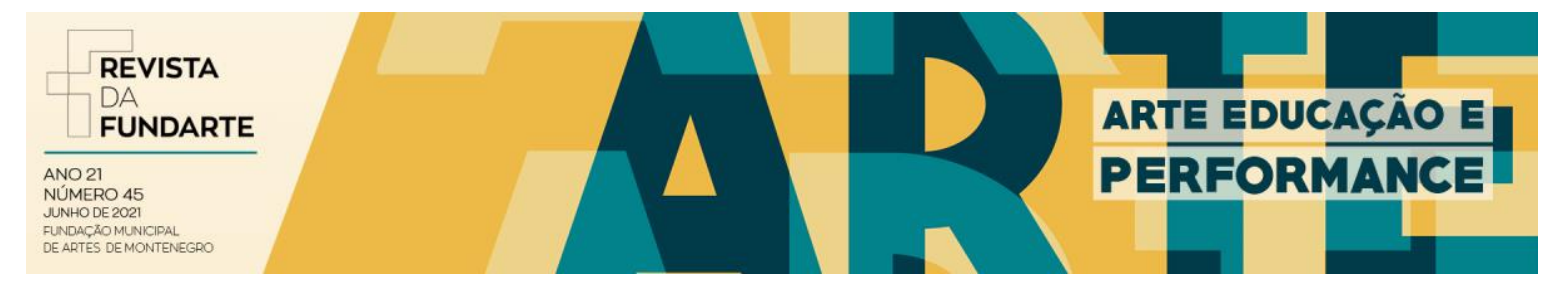

Doutorado. Escola de Comunicação e Artes da Universidade de São Paulo. São Paulo, 392 f. 2019.

SÁEZ, J; CARRASCOSA, S. Pelo cu: políticas anais. Trad. Rafael Leopoldo. Belo Horizonte, MG: Letramento, 2016.

SANTOS, F. R. da S. Lírica dissonante: o grotesco na lírica romântica brasileira considerações sobre aspectos do grotesco na poesia de Bernardo Guimarães e Cruz e Souza. Tese de Doutorado. Faculdade de Ciências e Letras da Universidade Estadual Paulista "Júlio de Mesquita Filho". Araraquara, 439 f. 2009.

SILVA, P. C. da; SILVA, M. C. C. A fotografia de Robert Mapplethorpe na perspectiva teórica de Vilém Flusser em Filosofia da Caixa Preta. Revista Eco Pós. Rio de Janeiro, Vol. 19, n. 3, p. 266-291, 2016.

SONTAG, S. Aids and its metaphors. New York, NY: Farrar, Straus \& Giroux, 1989. 